\title{
MICROMORPHOLOGY, MINERALOGY, AND GEOCHEMISTRY OF SEDIMENTS AT THE THAM LOD ROCK SHELTER ARCHAEOLOGICAL SITE IN MAE HONG SON, THAILAND: SUGGESTIONS OF A LATE PLEISTOCENE CLIMATE
}

\author{
Seriwat Saminpanya ${ }^{1, \mathrm{C}}$ and Nopporn Denkitkul ${ }^{2}$
}

\begin{abstract}
Sediments from an archaeological pit at the Tham Lod rock shelter in Mae Hong Son, Thailand, reveal sparse palaeoenvironment and palaeoclimate information in the north-western region of Thailand and Southeast Asia. This study is a pioneering work for the site. Micromorphological, mineralogical, and geochemical methods were applied for analyses. The sediment profile was divided into two zones: the upper 0-338 cm depth and the lower $338-450 \mathrm{~cm}$ depth. Intense chemical weathering occurred in the lower zone, indicated by low quantities of kaolinite and high chemical index of alteration (CIA, 64.55-73.36\%), reflecting greater humidity. The upper zone yielded mild $\mathrm{CIA}(<47.21 \%)$ and contained ubiquitous smectite, indicating drier conditions. Overall sediments (along the profile, $0-450 \mathrm{~cm}$ depth) were affected by leaching and thin section analyses suggested a wet/dry cycle during diagenesis under humid tropical conditions. Micromorphological and geochemical analyses indicated that mudstone, sandstone, and limestone were major parent materials of sediments deposited mainly in a fluvial environment in the lower zone, which changed to a colluvial environment in the upper zone. The palaeoclimate during 12,770-33,340 yr BP was in the Last Glacial Maximum Period, characterized by drier and cooler than the present climate. The period $\geq 33,340 \mathrm{yr}$ BP was wet and cool. Evidence of prehistoric human occupation, including bone and charcoal fragments, appeared in sediments in the upper zone, suggesting animal hunting for survival.
\end{abstract}

\section{Introduction}

The rock shelter at Tham Lod in Mae Hong Son, Thailand has been extensively studied by many scholars in particular of archaeology and geoarchaeology (e.g., Khaokhiew, 2003; Marwick and Gargan, 2011; Marwick, 2013; Chitkament et al., 2016). However, valuable information which can be retrieved from the site is palaeoclimate information, which is in scarce in the studied region. Marwick and Gargan (2011) focused on oxygen isotope sequence of bivalves from the site and addressed the Pleistocene monsoon variability in northwestern Thailand. They demonstrated that the area was under the conditions of wet during $\sim 35,000-20,000 \mathrm{yr}$ BP and dry during $\sim 20,000-12,000 \mathrm{yr}$ BP. The monsoon-climate variability for the more recent period, back to $\sim 400 \mathrm{yr} B P$, of the region was also derived from stalagmites and tree-rings (Clemens et al., 2010; Muangsong et al., 2014). Alternatively, we have been interested in a meaningful proxy, the sediment of the site, which records the palaeoclimatic conditions to the region during the late Pleistocene.

Unconsolidated sediment of the site is a crucial candidate to be studied in more detail and from a different viewpoint for valuable palaeoclimate data. A focus on analyzing sediment samples from the pit profiles can help reveal some information about the palaeoclimate and palaeoenvironment. The multiple techniques used in this research have been used to interpret the local and regional precipitation and humidity conditions (Sheldon and Tabor, 2009). The results of this study are beneficial to complete the data inventory of Thailand and Southeast Asia (SEA) and to reveal the palaeoclimate in terms of understanding the interrelationship between the prehistoric human habitat and the palaeoclimate in the late Pleistocene Epoch.

\section{Materials and Methods}

Micromorphological, mineralogical, and geochemical contexts are used in this work. Depositional sediments can record evidence or processes (Selley, 1985) that can be observed via micromorphology following the guidelines of Stoops et al. (2010). The aspect of geochemistry regarding the chemical processes of alteration, elemental signatures, and mineralogy, including clay-based minerals, can reveal the weathering intensity, sediment provenance, climatic environments, and anthropogenic input to the site.

\section{Study area}

The Tham Lod rock shelter site is located in the well-known archaeological pit in the Pang Mapha district in Mae Hong Son Province, Thailand. The shelter is located in a karst area at latitude $19^{\circ} 34^{\prime} 03^{\prime \prime} \mathrm{N}$ and longitude $98^{\circ} 16^{\prime} 46^{\prime \prime} \mathrm{E}$, with an elevation of $\sim 640 \mathrm{~m}$ above mean sea level (Fig. 1). The pit is situated in a boundary of the Tham Lod Natural and Wildlife Education Center. The details of its physical characteristics have already been reported by Marwick (2013) and Chitkament et al. (2016).

${ }^{1}$ Department of General Science, Faculty of Science, Srinakharinwirot University, Bangkok 10110, Thailand

${ }^{2}$ Faculty of Environment and Resource Studies, Mahidol University, Salaya, Nakhon Pathom 73170, Thailand

cCorresponding author: seriwat@g.swu.ac.th 


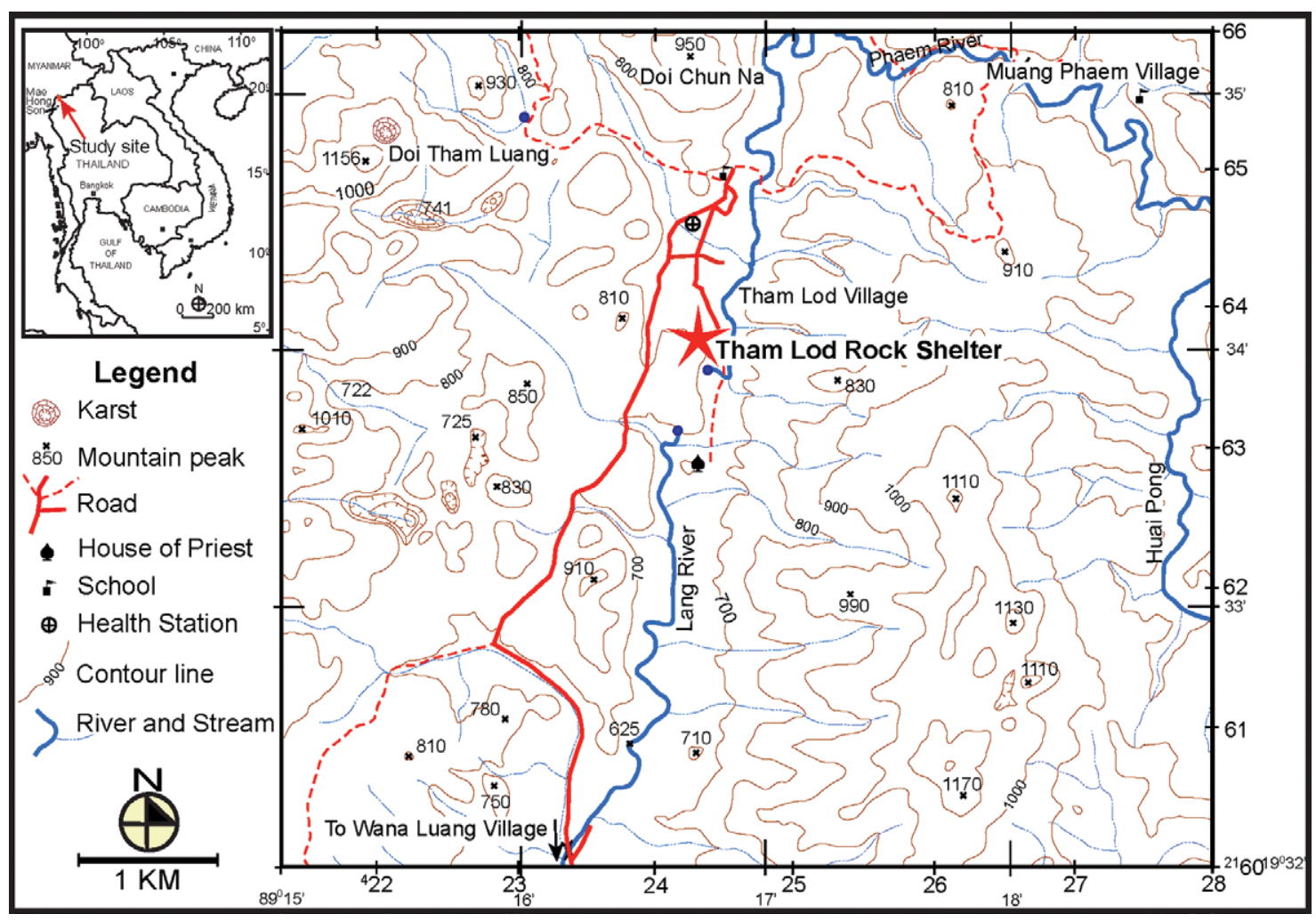

Figure 1. Location of Tham Lod rock shelter (adapted from a topographic map by the Royal Thai Survey Department, 1999).
The regional geology of the area surrounding the site consists of rocks composed of Silurian-Devonian phyllite and quartzite, Carboniferous clastic and chemical sedimentary rocks, Permian limestone, and Triassic granite (Department of Mineral Resources, Thailand, 2017). Permian limestone hosts the site and displays typical karst morphology, including rock shelters, caves, sinkholes, and polje. The rock shelter is situated near the Lang River, which contains gravel from different kinds of rocks, e.g., granite, andesite, chert, sandstone, shale, quartzite, and flint. The shelter (Fig. 2a) is the wall of an open doline basin filled with unconsolidated fluvial sediments of the Lang River located south of the basin (Khaokhiew, 2003). Some reports have
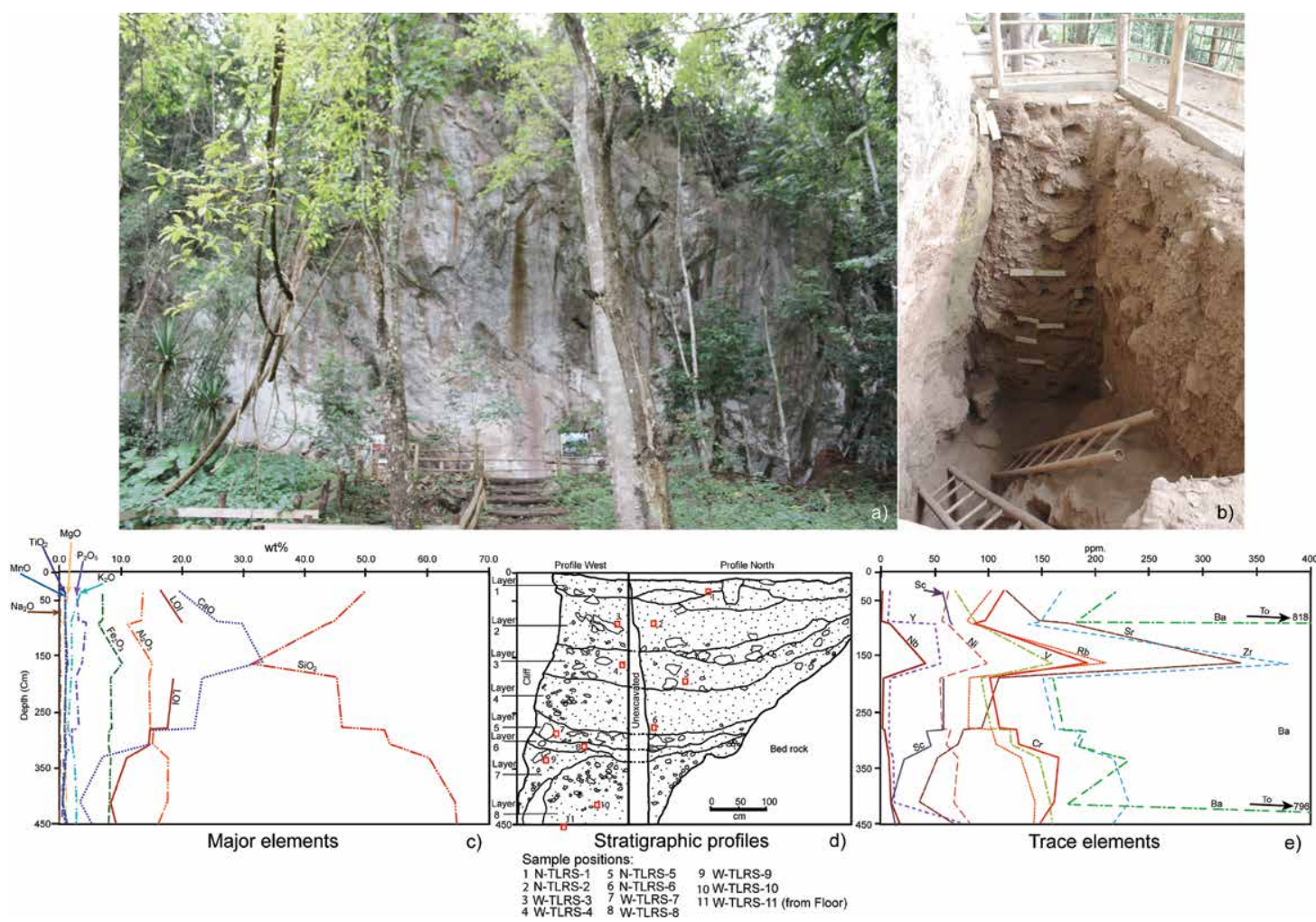

Figure 2. a) Tham Lod rock shelter, Pang Mapha district, Mae Hong Son Province, south view; b) profiles of the archaeological excavation pit under the shelter, as seen, the host limestone wall (left) profile west (middle) and profile north (right); c) and e) plots of major and trace elements along the profile in d). covered this site; e.g., Chitkament et al. (2016) described the stone artifacts of Hoabinhian culture, typified by sumatralith stones. The site is very significant in terms of its two human burials in the late Pleistocene Epoch (Marwick, 2013).

\section{Sample collection}

Unconsolidated sediment samples were collected from the profiles of an archaeologically excavated pit (4.5 meters deep) under the Tham Lod rock shelter. Eight layers of sediment were clearly designated based on different colors, textures, 
grain sizes, and archaeological materials observed in the field (Fig. 2d). Eleven samples weighing one or two kilograms each were collected and placed in plastic bags, and geochemical, grain size, and X-ray diffraction (XRD) analyses were performed. After this work, eight samples for polished thin section preparation were collected using Kubiena boxes. The field observation and sample collection were performed in November 2013 and the samples were stored in the dry and cool condition of the laboratory.

Field observations and descriptions were performed using the naked eye and a 10X loupe. A binocular microscope was used in a laboratory to observe the samples in more detail with the Munsell soil-color charts (Munsell Color (Firm), 2012) for color description. The particle size analysis employed the classic hydrometer method (Bedaiwy, 2012). The polished thin sections were examined under a polarizing microscope following the guidelines of Stoops et al. (2010). The XRD Philips X'Pert with MPD software was assigned to qualitatively analyze clay minerals with sample preparation following the standard method of Jackson (2005) by using ethylene glycol treatment before launching the XRD analysis. The chemical composition of the samples was obtained by X-ray fluorescence (XRF) on a Philips Magix Pro PW 2400 instrument with a sequential wavelength dispersive spectrometer, and sixteen international standards were run from the U.S. Geological Survey Reference Material (AGV-2, BCR-2, BHVO-2, BIR-1, DNC-1, DTs-2, GSP-2, QLO-1, RGM-1, STM-1, and W-2), International Atomic Energy Agency (SOIL-5 and SOIL-7), and British Chemical Standards (No. 368, No. 393, and No. 372/1). The XRF sample preparations included fused beads (a mixture of sample+lithium bromide+lithium) for major element analysis and pressed powders (a mixture of sample+boric acid+XRF multi-mix) under pressure of eighteen tons for trace element analysis. The loss on ignition (LOI) was determined by weight loss after heating approximately 1.0 grams of the powdered sample at $1,000^{\circ} \mathrm{C}$ for 2 hours. LOI is used to estimate organic and carbonate contents of the studied samples. Organic matter is oxidized at $\sim 500-550{ }^{\circ} \mathrm{C}$ and then carbonate will be combusted at $800-1000^{\circ} \mathrm{C}$ (Dean, 1974; Bengtsson and Enell, 1986; Heiri et al., 2001). The intensity of chemical weathering of sediments is illustrated by the chemical index of alteration ( $\mathrm{CIA}$ ) and we used an equation proposed by Nesbitt and Young (1982) as follows:

$$
\mathrm{CIA}=100 \times \frac{\mathrm{Al}_{2} \mathrm{O}_{3}}{\mathrm{Al}_{2} \mathrm{O}_{3}+\mathrm{CaO}+\mathrm{K}_{2} \mathrm{O}+\mathrm{Na}_{2} \mathrm{O}}
$$

The principle of the equation relates to feldspar weathering by hydration and clay mineral products and/or the presence of alkali elements ( $\mathrm{K}$ and $\mathrm{Na}$ ) in sediments. An elevated $\mathrm{Al}$ content may be linked with increasing clay content and decreasing $\mathrm{Ca}, \mathrm{K}$, and $\mathrm{Na}$ contents, causing higher CIA values (Nesbitt and Young, 1982). The dates for the sediments were derived from Marwick and Gagan (2011), where this issue was discussed in detail.

\section{Results}

\section{Field and binocular observations}

The sediments were mainly allogenic, and smaller amounts of rocks were present. Layers 1 and 2 contain two human burials at 50 and $80 \mathrm{~cm}$ depths, respectively, with shells and artifacts, such as glass beads, potsherds, and metals (Marwick and Gagan, 2011). Layer 3 contains clay and silt particles with charcoal, calcretes, and quartzite and limestone pebbles. Layers 4 and 5 contain more abundant animal bones and stone tools, while layers 6 and 7 have slight amounts of these materials. Layer 8 has no archaeological objects.

Based on field observations, the lower part, especially layers 7 and 8, contains abundant pebbles and cobbles, mainly composed of sandstone. Layers 1 to 6 have less abundant pebbles and cobbles but also include limestone fragments fallen from the cliff, calcretes, travertine fragments, mica grains, and bone and charcoal fragments. The field descriptions are shown in Table 1.

Observations via binocular microscopy show that the color of the sediment matrix is brown (7.5YR4/4). Most samples show a blocky aggregate structure. Angular limestone fragments and subrounded quartz grains appear in most of the samples. A description of the matrix of eight samples is shown in Table 2.

\section{Particle size analysis}

The particle size analysis from eleven samples is plotted in a diagram in Figure 3. Layers 1 and 3 contain more sand particles, and the number of sand particles decreases in the deeper parts (layers 6, 7, 8, 9, and 11).

\section{Thin section observation}

The matrix of the profile was inspected via thin sections. Most show a loose arrangement and poorly-sorted fabrics. Brown clay aggregates are observed and contain inclusions of quartz grains. Fe/Mn-oxide nodules are abundant in almost all samples. The quartz grains are poorly sorted, and bone fragments appear in some samples. More detailed descriptions are presented in Table 3 and Figure 4. 


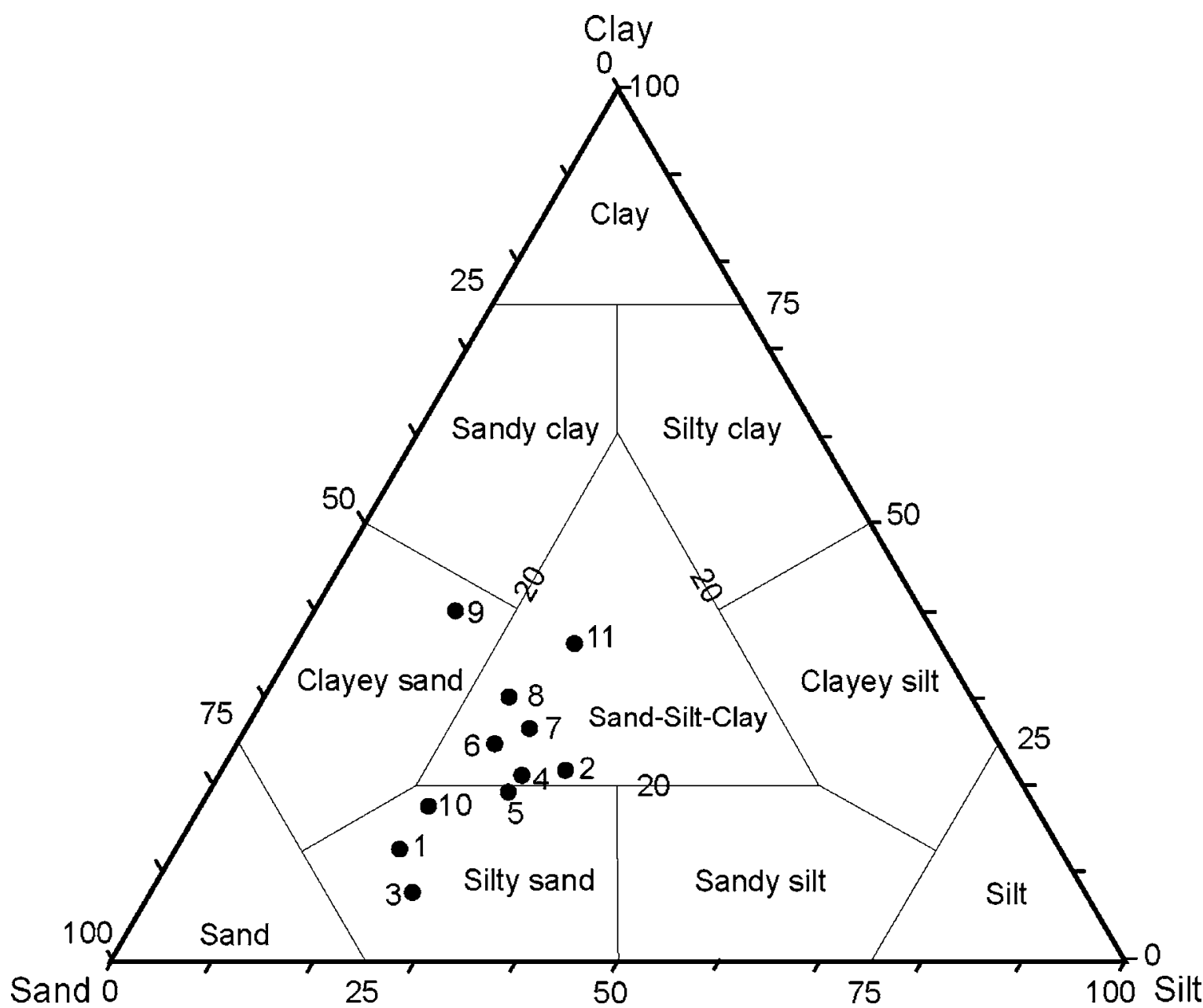

Mineralogy

The qualitative XRD results show the amounts of clay minerals (kaolinite, illite, and smectite), quartz, and calcite in the samples (Fig. 5). Layers 7 and 8 contain higher levels of kaolinite, but layers 1 to 6 have trace amounts of this mineral. In contrast, smectite shows dominant or large amounts in the upper layers, especially layers 1 to 4 , and then decreases to small quantities in the lower layers 7 and 8 .

\section{Geochemistry}

Based on the differences in element contents in the profile, the profile can be divided into two

zones (upper from 0-338 cm depth and lower from 338-450 cm depth) (Fig. 2). All of the element contents are presented in Table 4.

\section{Discussion}

Micromorphology, mineralogy, and geochemistry of the Tham Lod site in its archaeological regional context and palaeoclimate are discussed in this section.

\section{Micromorphology}

The appearances of the sediments presented in Figure 4 and the description of sediment observations in Tables 1-3 indicate that most clasts are poorly sorted, suggesting a fluvial environment with a strong current in terms of deposition, especially in the lower zone. Some layers consist of a variety of grain sizes, with pebbles and cobbles of various rock types. The gravel is mixed with reddish brown and yellowish brown clay, and the coarse particles are poorly sorted. The upper zone reflects the fluvial environment, together with the effects of air-fall materials, e.g., dust and rock debris, and anthropogenic sediments. The upper zone contains large angular limestone fragments fallen from the overhanging wall of the shelter. This feature suggests a dominantly colluvial environment. The lower zone has poorly sorted clastic sediments and aggregates with various particle sizes from clay to sand with mostly sub-angular to angular shapes, as well as ubiquitous pebbles and cobbles. This combination suggests that the water currents were very strong under the condition of the channel entrenchment of the Lang River, and during the flooding period of the river, its sediments would be disturbed. These sediments represent the fluvial facies associated with the palaeo-river Lang, now located approximately 100 meters north of the site. The transition boundary between these two depositional environments took place at approximately 32,000 yr BP (Marwick and Gagan, 2011). 
Wet/dry features chiefly involve water retention in sediments and the reduction and oxidation of Fe/Mn by chemical Table 1. Description of sediments from field observations.

\begin{tabular}{|c|c|c|}
\hline Layer & $\begin{array}{l}\text { Upper to Lower Limits } \\
\text { of Layer, } \mathrm{cm}^{\mathrm{a}}\end{array}$ & Description \\
\hline $\begin{array}{l}\text { Layer } 1 \\
\text { (top layer) }\end{array}$ & $0-72$ & $\begin{array}{l}\text { The matrix is mainly composed of clay and silt particles. The reddish clay matrix } \\
\text { incorporates very fine mica grains. Boulders of quartzite are well rounded and have low } \\
\text { sphericity. }\end{array}$ \\
\hline Layer 2 & $72-141$ & $\begin{array}{l}\text { The matrix is composed of small pieces of charcoal and bone with clay, plant roots, mica } \\
\text { grains }(1.5 \mathrm{~mm} \text { across), and white materials. Very angular limestone gravel with a maximum } \\
\text { size of } 7 \times 5 \times 1.5 \mathrm{~cm} \text { is present. Small pieces of broken stalagmites and stalactites are } \\
\text { found. In the upper part of the layer are platy limestone fragments and a sandstone pebble } \\
(10 \times 20 \times 30 \mathrm{~cm}) \text {. }\end{array}$ \\
\hline Layer 3 & $141-207$ & $\begin{array}{l}\text { The matrix is composed of clay and silt particles with an inclusion of charcoal. Calcretes } \\
\text { have irregular shapes }(5 \times 4 \times 3 \mathrm{~cm} ; 3 \times 3.6 \times 1.6 \mathrm{~cm}) \text {. Unknown green materials are present } \\
\text { and a rounded quartzite pebble }(10 \times 30 \times 15 \mathrm{~cm}) \text { with low sphericity. Angular limestone } \\
\text { pebbles }(25 \times 30 \times 25 \mathrm{~cm}) \text { with low sphericity are found. }\end{array}$ \\
\hline Layer 4 & $207-288$ & $\begin{array}{l}\text { In a matrix of clay and silt particles are abundant small pieces of bones, some calcretes } \\
\text { (max. } 3 \mathrm{~mm} \text { across) and small numbers of mica grains }(<1 \%) \text {. Black materials, probably } \\
\text { charcoal, also appear. Well-rounded quartzite pebbles }(\max .15 \times 7 \times 9 \mathrm{~cm}) \text { with low } \\
\text { sphericity and angular limestone pebbles (max. } 10 \times 15 \times 5 \mathrm{~cm}) \text { are found. }\end{array}$ \\
\hline Layer 5 & $288-317$ & $\begin{array}{l}\text { The yellow matrix is composed mainly of clay and silt with less than } 1 \% \text { muscovite grains } \\
(<1 \mathrm{~mm} \text { across). Clastic materials in this layer are coated with lime. Some calcretes are } \\
\text { found. Angular gravel is abundant }(>80 \%) \text { with an average size of } 3 \times 5 \times 4 \mathrm{~cm} \text {. A very } \\
\text { angular pebble of slate }(1.5 \times 4 \times 2.5 \mathrm{~cm}) \text { with low sphericity is present. }\end{array}$ \\
\hline Layer 6 & $317-338$ & $\begin{array}{l}\text { The matrix is composed of mainly clay particles with white bone fragments and angular to } \\
\text { subangular quartz gravel with low sphericity (max. } 3 \times 1.5 \times 2.5 \mathrm{~cm} \text { ) are found. Black angular } \\
\text { pebbles of travertine (max. } 8 \times 5 \times 4 \mathrm{~cm} \text { ) with low sphericity are present. }\end{array}$ \\
\hline Layer 7 & $338-450$ & $\begin{array}{l}\text { The matrix is composed of clay, quartz sand, and marl rock. Clay with grey-black spots is } \\
\text { present in lenses }(20 \times 70 \mathrm{~cm} \text { ) along with very angular black chert granules (max. } 2 \times 1 \times 0.5 \\
\mathrm{cm}) \text {. A layer of quartzite pebbles (up to } 2.5 \times 4 \times 3 \mathrm{~cm} \text { ), which are very angular to well- } \\
\text { rounded and have low sphericity, is found. }\end{array}$ \\
\hline $\begin{array}{c}\text { Layer } 8 \\
\text { (bottom layer) }\end{array}$ & $338-450+$ & $\begin{array}{l}\text { This layer is divided into } 2 \text { sublayers: } \\
\text { 1) Upper layer - The matrix is composed of clay with sand-size mica and quartz particles. } \\
\text { The layer contains well-rounded and moderately spherical pebbles and cobbles (max. } \\
7 \times 6 \times 18 \mathrm{~cm}) \text { of mainly grey sandstone }(\sim 80 \%) \text {. } \\
\text { 2) Lower layer - The layer contains brown-red clay, angular to rounded quartz sand, } \\
\text { granules }(<2 \%) \text {, and white mica grains }(\sim 1 \mathrm{~mm} \text { across). }\end{array}$ \\
\hline
\end{tabular}

${ }^{a}$ Note that layers are nonparallel. The numbers shown here represent the maximum thicknesses.

processes and include two main features: Mn-Fe-oxide and redox pedo-features. The first feature refers to Fe/Mn-oxides in sediments such as impregnated Fe/Mn nodules (Blokhuis et al., 1969; Kabakchiev and Galeva, 1973; Tsuji et al., 1975; Sleeman and Brewer, 1984; Blokhuis et al., 1990; Tawornpruek et al., 2006). The first feature found in the thin sections is the presence of Fe/Mn coatings, Fe/Mn hypocoatings, and Mn nodules (Figs. 4d, 4g). These features indicate the conditions of humidity, wet/dry cycles and the leaching process during diagenesis at the study site. The existence of the blocky and granular textures of clay aggregates, as well as oxic materials in almost all samples, indicate that the sediments were in the pedogenic process of clay cementation, and the water availability in the sediments implies a humid climate. The calcitic crystallitic $b$-fabric features in most samples are derived from limestone fragments by solutions dissolved from the limestone host rock of the shelter, percolated through the voids and cavities and then precipitated as calcretes during diagenesis. This interpretation supports the hypothesis that after their deposition, sediments were subjected to alternately wet and dry conditions. The abundant limestone fragments, calcretes, and calcitic crystallitic b-fabric features in the upper zone layers correspond to high $\mathrm{CaO}$ contents and high LOI (Santisteban et al., 2004). LOI shows higher values in the upper zone, which suggests that the upper zone was affected by a higher rate of deposition by air-fall particles.

The richness in oxic materials (e.g., Fe/Mn-oxides) represents water retention and high leaching in sediments. Oxic materials and microstructure aggregates are found at depths between 288 and $450 \mathrm{~cm}$ (samples W-TLRS-7, 8, 9, 10, and 11). The aggregates are cemented by clay and silt particles. From the grain size analyses, clay fractions dominate in these samples $(26.8 \%, 29.8 \%, 39.8 \%, 17.8 \%$, and $36.2 \%$, respectively). Sample W-TLRS-10 (at $412 \mathrm{~cm}$ depth) shows 
Table 2. Description of sediment samples from observations via a binocular microscope.

\begin{tabular}{|c|c|c|c|}
\hline Sample/Layer & $\begin{array}{l}\text { Upper to Lower } \\
\text { Limits of Layer, } \\
\text { cm }^{\text {a }}\end{array}$ & $\begin{array}{l}\text { Depth of } \\
\text { Sampling, } \\
\text { cm }\end{array}$ & Description \\
\hline $\begin{array}{c}\text { N-TLRS-1 } \\
\text { (Layer 1) }\end{array}$ & $0-72$ & 35 & $\begin{array}{l}\text { The colour of the layer is brown (7.5YR4/4) with loose arrangement of } \\
\text { subangular to well-rounded quartz grains. Blocky aggregations of soil and } \\
\text { muscovite grains (up to } 3 \times 1 \mathrm{~mm} \text { ) are found. }\end{array}$ \\
\hline $\begin{array}{c}\text { N-TLRS-2 } \\
\text { (Layer 2) }\end{array}$ & $72-141$ & 88 & $\begin{array}{l}\text { Blocky aggregations of soil and loose arrangements poorly sorted coarse } \\
\text { grains of quartz are cemented by brown }(7.5 \mathrm{YR} 4 / 4) \text { clay. Muscovite grains } \\
(\sim 0.2-0.5 \mathrm{~mm}) \text { and white limestone fragments }(3 \times 3 \mathrm{~mm}) \text { are found. }\end{array}$ \\
\hline $\begin{array}{c}\text { N-TLRS-5 } \\
\text { (Layer 3) }\end{array}$ & $141-207$ & 190 & $\begin{array}{l}\text { The matrix colour is brown (7.5YR4/4). Polycrystalline calcite aggregates (max. } \\
7 \times 9 \mathrm{~mm}) \text { are found. Blocks with angular and low sphericity limestone fragments } \\
(8 \times 5 \mathrm{~mm}) \text { are coated by reddish-brown clay. }\end{array}$ \\
\hline $\begin{array}{l}\text { N-TLRS-6 } \\
\text { (Layer 4) }\end{array}$ & $207-288$ & 280 & $\begin{array}{l}\text { Quartz sand grains (max. } 0.5 \times 0.5 \mathrm{~mm}) \text { are coated by brown clay }(7.5 \mathrm{YR} 4 / 4) \text {. } \\
\text { Aggregations of carbonate nodules (max. } 6 \times 5 \mathrm{~mm} \text { ), white bone fragments and } \\
\text { angular to subangular limestone fragments }(\max .1 .5 \times 1 \mathrm{~mm} \text { ) are present. }\end{array}$ \\
\hline $\begin{array}{l}\text { W-TLRS-7 } \\
\text { (Layer 5) }\end{array}$ & $288-317$ & 283 & $\begin{array}{l}\text { Brown ( } 7.5 \mathrm{YR} 4 / 4) \text { clay forms the matrix. Angular calcite grains (max. } 0.05 \mathrm{~mm} \\
\text { across) and limestone fragments (max. } 0.2 \mathrm{~mm} \text { across) with low sphericity are } \\
\text { present. }\end{array}$ \\
\hline $\begin{array}{l}\text { W-TLRS-8 } \\
\text { (Layer 6) }\end{array}$ & $317-338$ & 309 & $\begin{array}{l}\text { Brown (7.5YR4/4) clay forms the matrix. Angular limestone fragments (max. } \\
7 \mathrm{~mm} \text { across) with low sphericity and aggregated calcite crystals }(\sim 1.5 \mathrm{~mm} \\
\text { across) are present. }\end{array}$ \\
\hline $\begin{array}{l}\text { W-TLRS-9 } \\
\text { (Layer 7) }\end{array}$ & $338-450$ & 333 & $\begin{array}{l}\text { The colour of aggregated clay in the matrix is brown (7.5YR } 4 / 4 \text { ). Calcite grains } \\
\text { (up to } 1.5 \mathrm{~mm} \text { across) are found. Angular limestone fragments (up to } 3.5 \mathrm{~mm} \\
\text { across) with low sphericity are present. }\end{array}$ \\
\hline $\begin{array}{c}\text { W-TLRS-10 } \\
\text { (Layer 8) }\end{array}$ & $338-450+$ & 412 & $\begin{array}{l}\text { The matrix consists of brown ( } 7.5 \mathrm{YR} 4 / 4) \text { clay. A calcite crystal }(0.5 \mathrm{~mm} \text { across) } \\
\text { and sub-rounded quartz grains (max. } 1 \mathrm{~mm} \text { across) are found. Aggregations of } \\
\text { angular to sub-angular limestone fragments (max. } 1.5 \mathrm{~mm} \text { across) are present. }\end{array}$ \\
\hline
\end{tabular}

${ }^{a}$ Note that layers are nonparallel. The numbers shown here represent the maximum thicknesses.

reddish-brown clay cementation and clay aggregates that imply more extensive oxic materials formed during water retention in the lower zone than in the upper zone, which corresponds with their chemical index of alteration (CIA) and mean annual precipitation (MAP) values.

Although sample N-TLRS-6 (280 cm depth) is located in the upper zone, it shows distinctively intense clay aggregates, granular microstructures, and clay cementations. This combination is regarded as the effect of highly oxic materials. This sample is different from all other samples from the upper zone, indicating an interrupting period of more humid climate conditions. However, the other samples in the upper zone (N-TLRS-1, 2, W-TLRS-3, 4, and N-TLRS-5, from 0 to $207 \mathrm{~cm}$ depth) contain less oxic materials and an aggregate structure, suggesting that their deposition took place in a less humid environment.

\section{Mineralogy}

Kaolinite is a climatic indicator and the product of a high weathering intensity environment (Dixon, 1989; Alam et al., 2008; Hong et al., 2013). The results reveal that the kaolinite contents of the lower zone (from 338 to $450 \mathrm{~cm}$ depths in particular) are more prominent than those of the upper zone. This result suggests strong chemical weathering and more humid conditions or tropical/subtropical climates for the lower zone. The less distinctive kaolinite peaks, but not those of smectite, in the upper zone reflect a low level of chemical weathering and a drier environment (Fig. 5). Smectite, an alteration product of mafic minerals, is usually stable in arid, semi-arid, warm and dry or temperate climates (Pal, 2014). It can exist for a short period under humid or tropical conditions and can readily transform to kaolinite (Pal et al., 1989; Bhattacharyya et al., 1993). Smectite usually forms in poorly drained tropical to subtropical areas of low relief, marked by flooding in the humid seasons and substantial pore water retention in the soil during dry seasons (Chamley, 1989). These results strongly confirm that the upper zone of the Tham Lod rock shelter represents drier conditions.

\section{Geochemistry}

Although the profile has been subdivided into two zones as mentioned above, geochemical variations can be found at the depths of $93 \mathrm{~cm}, 164 \mathrm{~cm}, 412 \mathrm{~cm}$, and $450 \mathrm{~cm}$ (Fig. 2). At $93 \mathrm{~cm}$, there are relatively low $\mathrm{Al}_{2} \mathrm{O}_{3}, \mathrm{Fe}_{2} \mathrm{O}_{3}$, and $\mathrm{TiO}_{2}$ contents but rich in $\mathrm{P}_{2} \mathrm{O}_{5}, \mathrm{Y}, \mathrm{Sr}$, and $\mathrm{Ba}$ contents. This layer contains abundant fragments of bone reflecting the high 
Table 3. Description of thin section samples.

\begin{tabular}{|c|c|c|c|}
\hline $\begin{array}{l}\text { Sample/ } \\
\text { Layer }\end{array}$ & $\begin{array}{l}\text { Upper to } \\
\text { Lower Limits } \\
\text { of Layer, } \mathrm{cm}^{\mathrm{a}}\end{array}$ & $\begin{array}{c}\text { Depth of } \\
\text { Sampling, } \\
\text { cm }\end{array}$ & Description \\
\hline $\begin{array}{c}\text { N-TLRS-1/ } \\
\text { (Layer 1) }\end{array}$ & $0-72$ & 35 & $\begin{array}{l}\text { The sediment is loose and poorly sorted. Quartz grains }(<0.1-0.2 \mathrm{~mm} \text { across, } 40 \%) \text {, } \\
\text { are mainly angular to sub-angular, but some are well-rounded. Nodules of quartz silt } \\
\text { to sand particles are present. There are some muscovite grains }(<1 \%) \text { with prismatic } \\
\text { angular and sub-rounded shapes. Calcite crystals (max. } 1.2 \times 1 \mathrm{~mm}, 50 \%) \text { with blocky, } \\
\text { lenticular, cylindrical, or tabular habits are present. } \\
\text { The groundmass is composed of Fe-oxide coatings with yellow-brown colour }(10 \%) \\
\text { on the nodules. The nodules are in aggregates with well-rounded shapes }(\sim 0.1 \mathrm{~mm} \\
\text { across). Bone and charcoal fragments are also found. }\end{array}$ \\
\hline $\begin{array}{c}\text { N-TLRS-2/ } \\
\text { (Layer 2) }\end{array}$ & $72-141$ & 88 & $\begin{array}{l}\text { The texture is mainly loose and poorly sorted. Quartz grains }(0.05-1.2 \mathrm{~mm} \text { across }) \\
(40 \%) \text { are mainly angular to well-rounded with low to high sphericity. Individual grains } \\
\text { contain cracks, exhibit blocky, stubby, and prismatic habits and form aggregates }(20 \%) \\
\text { with granular habit (clear reddish-brown colour). Quartz grains also appear as an } \\
\text { inclusion in a nodule. Calcite crystals show b-fabric }(\sim 5 \%) \text {. Fe-oxide hypocoatings } \\
\text { also appear in the aggregates }(15 \%) \text {. Bone and quartzite fragments are found. Voids } \\
\text { account for approximately } 20 \% \text {. }\end{array}$ \\
\hline $\begin{array}{c}\text { W-TLRS-5/ } \\
\text { (Layer 3) }\end{array}$ & $141-207$ & 190 & $\begin{array}{l}\text { The sediment is mainly loose and poorly sorted. Quartz sand grains }(\sim 60 \%) \text { are } \\
\text { angular to well-rounded with moderate sphericity and have granular, blocky or } \\
\text { cylindrical habits. Calcite crystals }(<0.1-0.2 \mathrm{~mm} \text { across, } \sim 5 \%) \text { show b-fabric, and } \\
\text { some crystals }(\sim 0.3-0.2 \mathrm{~mm} \text { across }) \text { have rhombohedral shape with cleavages. There } \\
\text { are } 35 \% \text { cavities. Bone, sandstone, and limestone fragments are present. }\end{array}$ \\
\hline $\begin{array}{c}\text { N-TLRS-6/ } \\
\text { (Layer 4) }\end{array}$ & $207-288$ & 280 & $\begin{array}{l}\text { The sediment is in loose aggregates with abundant plasma. The aggregates contain } \\
\text { inclusions of clastic quartz grains. Cracks account for } \sim 15 \% \text { of voids. } \\
\text { Bone fragments }(\sim 5 \%) \text { display yellow-orange colour (PPL) with sizes ranging from } \\
<0.1 \mathrm{~mm} \text { to } 2.5 \times 3 \mathrm{~mm} \text { and are most abundant in this layer. The bone fragments are } \\
\text { included in clay aggregates, and some are single grains. Fe-oxide hypocoatings occur } \\
\text { in aggregates and on quartz grains. There are some Fe/Mn-oxide nodules }(0.03-0.05 \\
\mathrm{mm} \text { across, } \sim 10 \%) \text {. } \\
\text { The groundmass shows crystalline b-fabric due to the presence of calcite grains, and } \\
\text { some calcite grains are observed inside aggregates. Quartz sand grains }(0.5 \times 0.6 \mathrm{~mm} \\
\text { across) and quartz silt grains }(\sim 70 \%) \text { are poorly sorted and show blocky or prismatic } \\
\text { habits. }\end{array}$ \\
\hline $\begin{array}{c}\text { W-TLRS-7I } \\
\text { (Layer 5) }\end{array}$ & $288-317$ & 283 & $\begin{array}{l}\text { The sediments display granular aggregates that contain zigzag voids }(\sim 10 \%) \text {. The ratio } \\
\text { between oxic materials and carbonate materials is } 40: 60 \text {. Quartz sand grains }(<0.05 \\
\text { to } 1 \mathrm{~mm} \text { across, } 70 \%) \text { with blocky habits show sub-angular to angular to well-rounded } \\
\text { shapes, are poorly sorted and have moderate to high sphericity. Individual grains show } \\
\text { fractures. Coarse-grained quartz particles are mostly angular to sub-angular. Bone } \\
\text { fragments (max. } 0.2 \times 1 \mathrm{~mm},<5 \%) \text { are present in calcitic groundmass. } \\
\text { The groundmass contains a mixture of calcitic and oxic materials. Fe-oxides }(\sim 5 \%) \\
\text { coatings on groundmass and aggregates are reddish-brown. Fe/Mn-oxide nodules } \\
(\sim 10 \%) \text { with sizes of } \sim 1.5-0.05 \mathrm{~mm} \text { across are present. Compacted and poorly sorted } \\
\text { peds are of various sizes (from }<0.1 \mathrm{~mm} \text { to } 0.6 \times 0.8 \mathrm{~mm}) \text {, and some are found inside } \\
\text { large clay aggregates and abundant plasma microstructures. Crumb structure is rich } \\
\text { with clastic quartz inclusions. }\end{array}$ \\
\hline $\begin{array}{c}\text { W-TLRS-8/ } \\
\text { (Layer 6) }\end{array}$ & $317-338$ & 309 & $\begin{array}{l}\text { Abundant plasma microstructures in both crystallitic } b \text {-fabric and undifferentiated } \\
\text { b-fabric have proportions of } 50: 50 \text { and contain Fe-oxides }(\sim 20 \%) \text {. Crumb structure is } \\
\text { also present. Small curved and zigzag voids appear in the aggregates. Quartz grains } \\
(\sim 30 \%) \text { are mostly sub-angular to well-rounded and show blocky habits; sizes range } \\
\text { from }<0.05 \mathrm{~mm} \text { to } 0.1 \times 0.2 \mathrm{~mm} \text {. Some quartz grains are included in Fe/Mn-oxide } \\
\text { nodules. Fe/Mn-oxide nodules }(\sim 30 \%) 0.05-0.1 \mathrm{~mm} \text { across are present. Fe-oxides } \\
(\sim 10 \%) \text { coatings form on quartz grains, bone/charcoal fragments, and nodules. There } \\
\text { are some calcite crystals and limestone fragments. }\end{array}$ \\
\hline $\begin{array}{c}\text { W-TLRS-9/ } \\
\text { (Layer 7) }\end{array}$ & $338-450$ & 333 & $\begin{array}{l}\text { Clay aggregates are } \sim 0.1-6 \mathrm{~mm} \text { across. There are three types of b-fabric: } 1) \\
\text { undifferentiated b-fabric; } 2) \mathrm{crystallitic} b \text {-fabric; and } 3 \text { ) speckled b-fabric. Quartz grains } \\
\text { (from }<0.05 \mathrm{~mm} \text { to } 0.8 \times 1.2 \mathrm{~mm}, 80 \%) \text { are poorly sorted, well-rounded to angular; they } \\
\text { have low to high sphericity and prismatic, blocky and vermiform habits. Mica grains } \\
(\sim 5 \%) \text {, hypocoatings }(\sim 10 \%) \text {, and Fe/Mn-oxide nodules }(\sim 5 \%) \text { are present. Fe-oxides } \\
\text { coat clay aggregates and fill in fractures. }\end{array}$ \\
\hline
\end{tabular}


Table 3. (Continued).

\begin{tabular}{cccc}
\hline $\begin{array}{c}\text { Sample/ } \\
\text { Layer }\end{array}$ & $\begin{array}{c}\text { Upper to } \\
\text { Lower Limits } \\
\text { of Layer, } \mathbf{c m}^{\text {a }}\end{array}$ & $\begin{array}{c}\text { Depth of } \\
\text { Sampling, } \\
\mathbf{c m}\end{array}$ & \multicolumn{1}{c}{ Description } \\
\hline $\begin{array}{c}\text { W-TLRS-10/ } \\
\text { (Layer 8) }\end{array}$ & $338-450$ & 412 & $\begin{array}{l}\text { The groundmass shows plasma structures of calcitic crystallitic b-fabric and } \\
\text { undifferentiated b-fabric. Quartz grains }(<0.05 \mathrm{~mm} \text { to } 0.8 \times 1.2 \mathrm{~mm}, 40 \%) \text { are poorly } \\
\text { sorted and angular to well-rounded with low to high sphericity and have prismatic, } \\
\text { stubby, and vermiform habits. Mica grains }(\sim 5 \%), \text { hypocoatings }(\sim 30 \%), \text { and Fe/ } \\
\text { Mn-oxide nodules }(\sim 5 \%) \text { are present. Voids }(20 \%) \text { are curved and zigzag. Speckled } \\
\text { b-fabric is also found. Fe/Mn-oxides also appear in aggregates. Fe-oxides coat the } \\
\text { aggregates and fill in the voids. }\end{array}$ \\
\hline
\end{tabular}

${ }^{a}$ Note that layers are nonparallel. The numbers shown here represent the maximum thicknesses.

value of $\mathrm{P}_{2} \mathrm{O}_{5}$. $\mathrm{Sr}^{2+}$ substitutes readily for $\mathrm{Ca}^{2+}$ of calcite in limestone fragments in the layer. Ba reflects the rich illite or feldspar in the sediments due to the substitution of $\mathrm{Ba}$ for $\mathrm{K}$ in these minerals. Ba can be rich in karst soils e.g., in Italy (lacoviello and Martini, 2013). High Y probably comes along with carbonate sediments because of the similarity of the ionic size of Sr and $\mathrm{Ca}$ (Krauskopf and Bird, 1995).

At the depth of $164 \mathrm{~cm}$, there are several maximum values of some major and trace elements $\left(\mathrm{Fe}_{2} \mathrm{O}_{3}, \mathrm{MgO}, \mathrm{MnO}\right.$, $\mathrm{CaO}, \mathrm{Ni}, \mathrm{V}, \mathrm{Rb}, \mathrm{Y}, \mathrm{Nb}, \mathrm{Cr}, \mathrm{Sr}$, and $\mathrm{Zr}$ ). The abrupt change in climate condition to the highest episode is characterized by the maximum estimated temperature $\left(17.3^{\circ} \mathrm{C}\right)$. The sediment is rich in mafic elements $(\mathrm{Fe} / \mathrm{Mg} / \mathrm{Mn} / \mathrm{Ca} / \mathrm{Ni} / \mathrm{V} / \mathrm{Cr})$, indicating the heavy input of the products of sediment from older mafic source rocks. Some trace elements can be explained in the same way as the $93 \mathrm{~cm}$ depth and they may be derived from the same mafic sources. Except for Rb, a large-ion lithophile, and $\mathrm{Nb}+\mathrm{Zr}$, a high field-strength element, tend to be derived from felsic rocks (Krauskopf and Bird, 1995) because these elements are lithophile and incompatible and they usually end up in the crust (or felsic environment). $\mathrm{Zr}$ also reflects the minerals zircon and monazite in quartz sand particles in the studied sediment. At the depth of $412 \mathrm{~cm}$, and $450 \mathrm{~cm}$ the sediment was under the strong current, heavy rainfall, and high weathering rate, characterized by the $\mathrm{SiO}_{2}$ rich and less $\mathrm{CaO} / \mathrm{LO}$. Some traces are relatively high e.g., $\mathrm{V}, \mathrm{Rb}, \mathrm{Y}, \mathrm{Ba}$, and $\mathrm{Zr}$. These traces have their sources and behaviors of substitution as explained before. For example, Ba manifests the feldspar and mica, and $\mathrm{Zr}$ mirrors the quartz sand in the sediments.

\section{Weathering intensity}

The triangular diagram (Fig. 6) shows that the upper zone sediments have CIA values lower than those of the lower zone. This result suggests that the lower zone was affected by a higher chemical weathering intensity than the upper zone. A trend of higher alteration increases with the depth along the profile. Samples at depths between 338 and 450 $\mathrm{cm}$ in the lower zone are very similar with high CIA values and greater amounts of kaolinite than in the lower zone. These results suggest the distinctive chemical weathering of sediments and a humid environment. The CIA values of the upper zone sediments at depths between 35 and $338 \mathrm{~cm}$ are lower; i.e., less chemical weathering and higher contents of smectite in this zone reflect a drier environment or lower humidity.

\section{Palaeoprecipitation and palaeotemperatures}

Palaeoprecipitation or palaeorainfall in terms of mean annual precipitation (MAP) was derived by excluding $\mathrm{K}$ content from the CIA ( $\mathrm{CIA}-\mathrm{K})$. The values were estimated with the equation MAP $(\mathrm{mm} / \mathrm{yr})=221.1 \mathrm{e}^{0.0197(\mathrm{CIA}-\mathrm{K})}$ from Maynard (1992) using the major elements of samples that were converted to moles before calculation. The MAP values report the maximum and minimum of 935 and $687 \mathrm{~mm} \mathrm{yr}^{-1}$ in the lower zone, and of 447 and $309 \mathrm{~mm} \mathrm{yr}^{-1}$ in the upper zone (Fig. 7). These results demonstrate that past precipitation in the younger upper zone was less than that in the lower/ older zones. The levels of palaeorainfall before 33,340 yr BP were higher than in the younger period.

The palaeotemperature in degrees Celsius is estimated by the mean annual temperature (MAT) equation of Hamer et al. (2007), $\mathrm{T}\left({ }^{\circ} \mathrm{C}\right)=46.9 \mathrm{C}+4$.

$\mathrm{C}$ or clayeyness refers to the $\mathrm{Al} / \mathrm{Si}$ ratio after their wt\% oxides $\left(\mathrm{Al}_{2} \mathrm{O}_{3}\right.$ and $\left.\mathrm{SiO}_{2}\right)$ have been converted to moles. The equation is applicable to a wide range of palaeotemperature estimates (Hamer et al., 2007). The Al/Si ratio is related to silicate parent material during Al accumulation (Retallack et al., 2000). The MAT and MAP values of the samples are displayed in Figure 7 . The MAT had similar values throughout the profile $\left(10.88-12.98^{\circ} \mathrm{C}\right)$, except for the maximum value at a depth of $164 \mathrm{~cm}\left(17.32^{\circ} \mathrm{C}\right)$. These values can provide useful data for the palaeoclimate to the area. More work needs to be conducted in detail to refine these equations for the study area.

\section{Distinct and non-distinct humidity}

The kaolinite and smectite contents, CIA and MAP values agree well and reveal that the lower zone sediment, representing $\geq 34,130 \mathrm{yr}$ BP, experienced greater humidity than the upper zone, representing 12,270-33,340 yr BP (Marwick and Gagan, 2011). Kaolinite in the lower zone is at a higher level than in the upper zone, and the lower zones have low- 

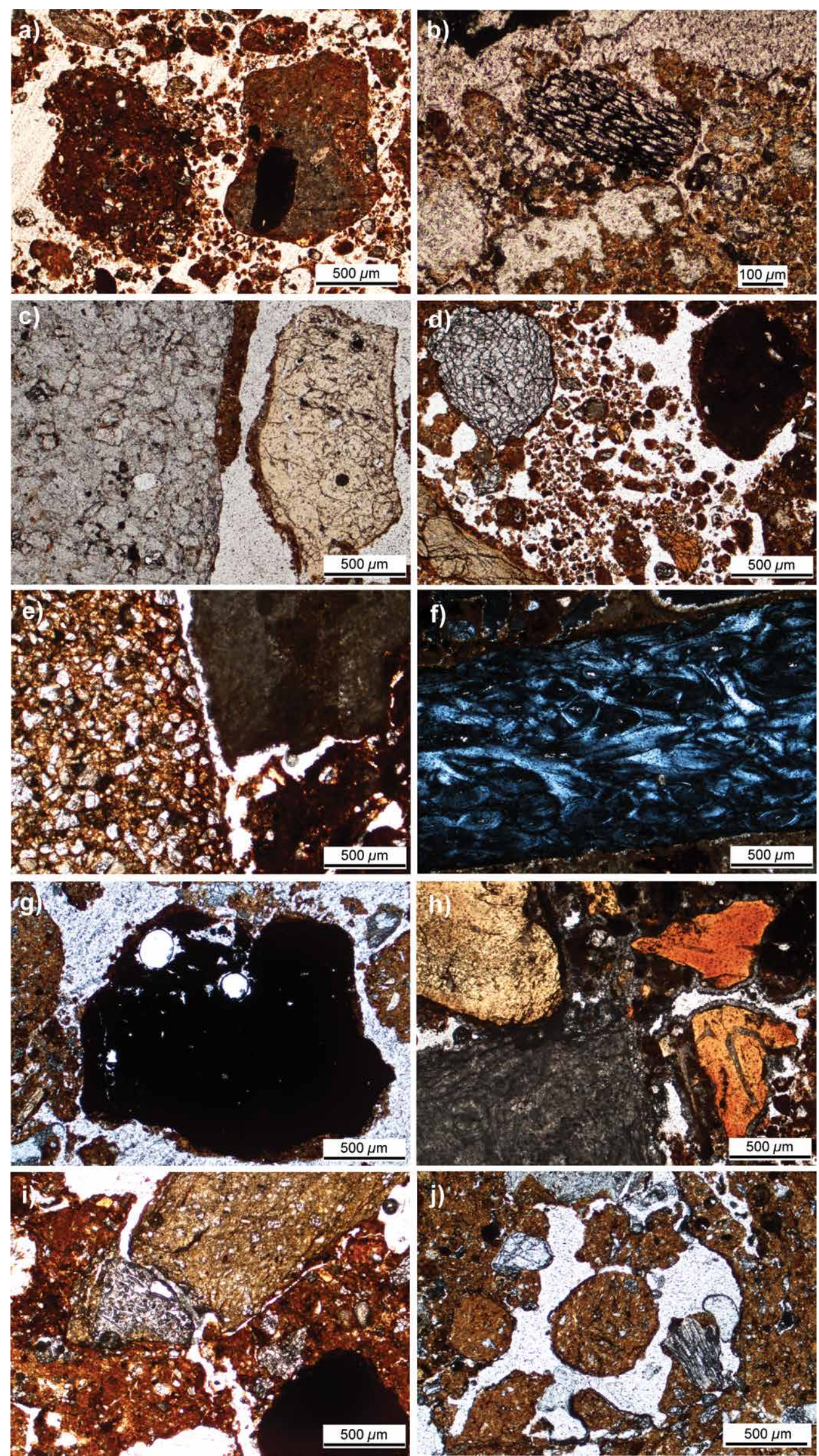

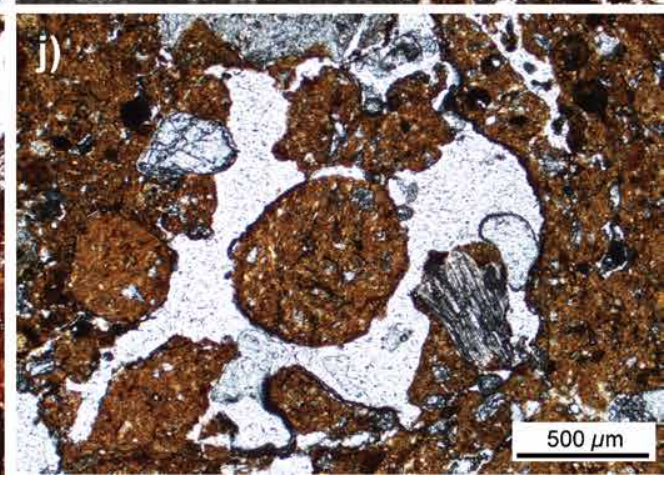

Figure 4. Features of thin sections under the microscope: a) clay aggregates with quartz inclusion (left), Mn-oxide nodule, and light-colored calcareous aggregate with black Mn-oxide inclusion (slide no. N-TLRS-1_A_N_2_a_PPL, in Layer 1); b) a charcoal fragment (centre) surrounded by clay and silt groundmass (slide no. N-TLRS1 C W 1 a $100 x$ PPL, in Layer 1); c) a quartzite fragment (left) and a yellow bone fragment (right) coated with brown clay aggregate containing quartz-silt inclusions (slide no. N-TLRS-2 C W 1 a PPL, Layer 2); d) fractured quartz grains (top left), Mn-oxide nodule (top right), yellow and orange bone fragments (bottom left and other areas), and groundmass containing brown clay aggregates with quartz silt inclusions (slide no. N-TLRS2 C W 1 b PPL, Layer 2); e) a sandstone fragment (left), a limestone fragment (top right), and a brown clay aggregate with quartz inclusions (bottom right) (slide no. N-TLRS-5_C_W_3_b_PPL, Layer 3); f) a piece of bone under cross polarization (grey area) with clay groundmass (top and bottom) (slide no. N-TLRS-6 B E 2 c XPL, Layer 4); g) a large black Mn-oxide nodule coated with brown clay, and brown clay aggregates (left and right) with a tiny bone fragment and quartz inclusions (slide no. W-TLRS-7 B N C PPL, Layer 5); h) yellow to orange bone fragments disseminated in the slide, some grains coated by tiny calcite grains, grey limestone fragment (lower left) containing a fossil of fusulinid, and groundmass of brown clay particles (slide no. W-TLRS-8_A_W_3_c PPL, Layer 6); i) reddish brown clay groundmass holding quartz grains, a yellow quartz-silt and clay aggregate (centre top), Mn-oxide (bottom right), and heavily fractured quartz grains (centre) (slide no. W-TLRS9_C_S_2_a_PPL, Layer 7); j) a yellow brown aggregate with quartz silt inclusions, a large quartz grain (top left), calcite aggregate (top centre), and mica grain showing 1-directional cleavage (centre right) (slide no. W-TLRS-10_B_N_PPL, Layer 8). 


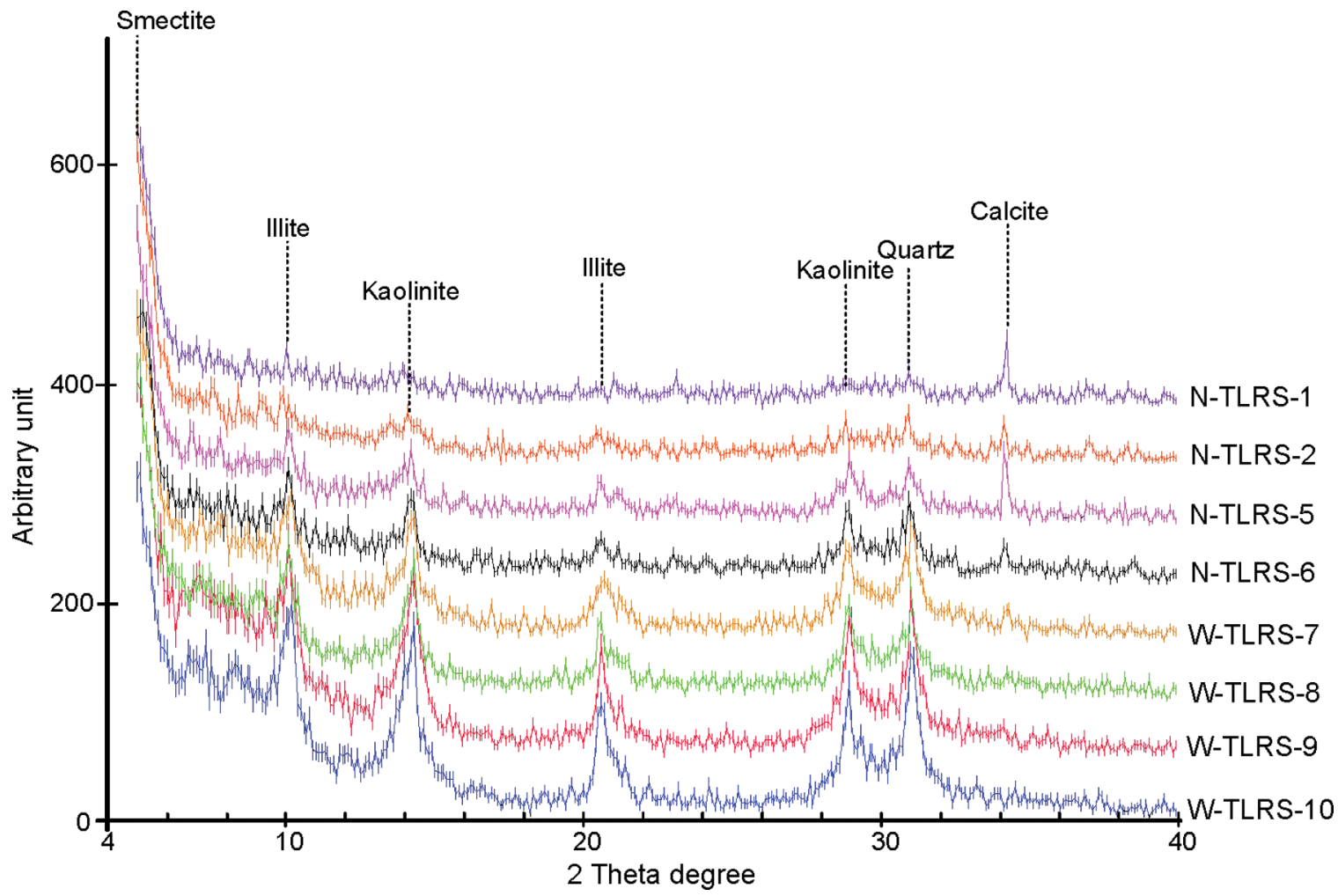

Figure 5. XRD peaks of clay minerals (smectite, illite, and kaolinite), quartz and calcite for sediment samples from different depths. er quantities of smectite, an aridity-indicative mineral. Conversely, the values of $\mathrm{ClA}$ and MAP are less prominent, and quantities of aridity-indicative smectite are higher in the upper zone. These results imply a lower humidity environment in the upper zone.

Other geochemical signatures

Trace elements in unconsolidated sediments are significant for the determination of various parameters, such as weathering inten-

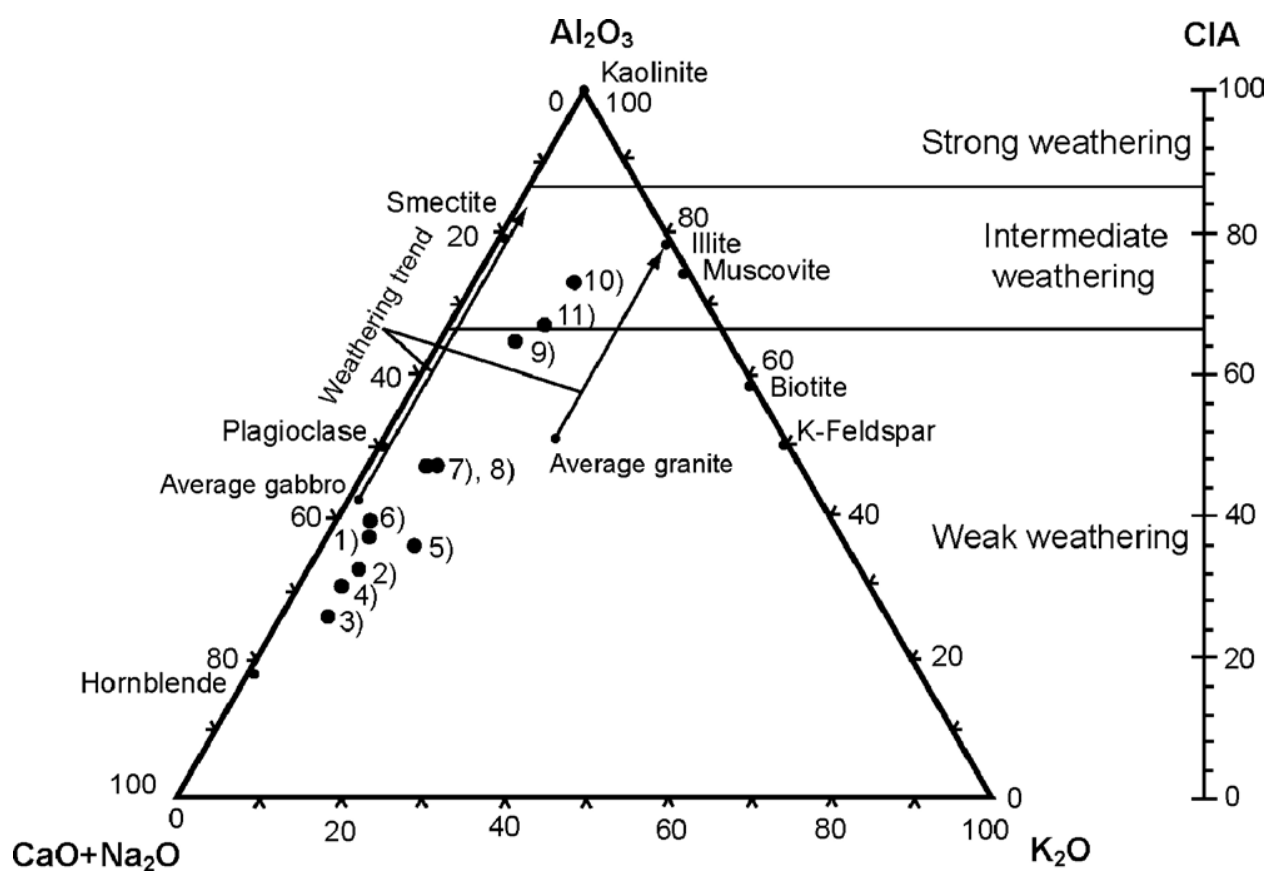

Figure 6. Triangular diagram of $\mathrm{ClA}$ using of $\mathrm{Al}_{2} \mathrm{O}_{3}, \mathrm{~K}_{2} \mathrm{O}$, and $\mathrm{CaO}+\mathrm{Na}_{2} \mathrm{O}$ contents (after Nesbitt and Young, 1982; 1984; 1989). [Sample ID/ Depth as in Figure 3]. sity, leaching, sediment provenance (Sheldon and Tabor, 2009), and palaeoclimate conditions (Aubert and Pinta, 1977). At this point, the ratios of $\mathrm{Ti} / \mathrm{Al}, \mathrm{Ba} / \mathrm{Sr}$, and other trace elements ascertain the provenance of sediments and palaeoclimate reconstruction.

$\mathrm{Ti} / \mathrm{Al}$ : provenance and weathering intensity

Ti/Al can be used for tracing sediment provenance; after wt $\%$ oxide conversion to molecules of $\mathrm{TiO}_{2}$ and $\mathrm{Al}_{2} \mathrm{O}_{3}$. This ratio is significant for parent granitic or basaltic rocks. The $\mathrm{Ti}$ concentration may vary between different rock types, while the concentration of $\mathrm{Al}$ is relatively constant, but both are immobile. The ratio should remain constant during diagenesis if the $\mathrm{pH}$ is $5.5-8$ (Sheldon, 2006). Therefore, if this ratio increases, the sediments might come from a more mafic parent. Moreover, the ratio also determines the level of weathering intensity; the lower the ratio is, the higher the leaching process (high weathering intensity), and their provenance possibly contained mudstone and sandstone (Maynard, 1992; Sheldon, 2006) (Fig. 8). Chen et al. (2013) found that Ti/Al decreases due to distance from the parent host. The Ti/Al values are low throughout the profile with an average molar ratio of 0.080 , suggesting that the sediments existed under conditions of high weathering intensity. 


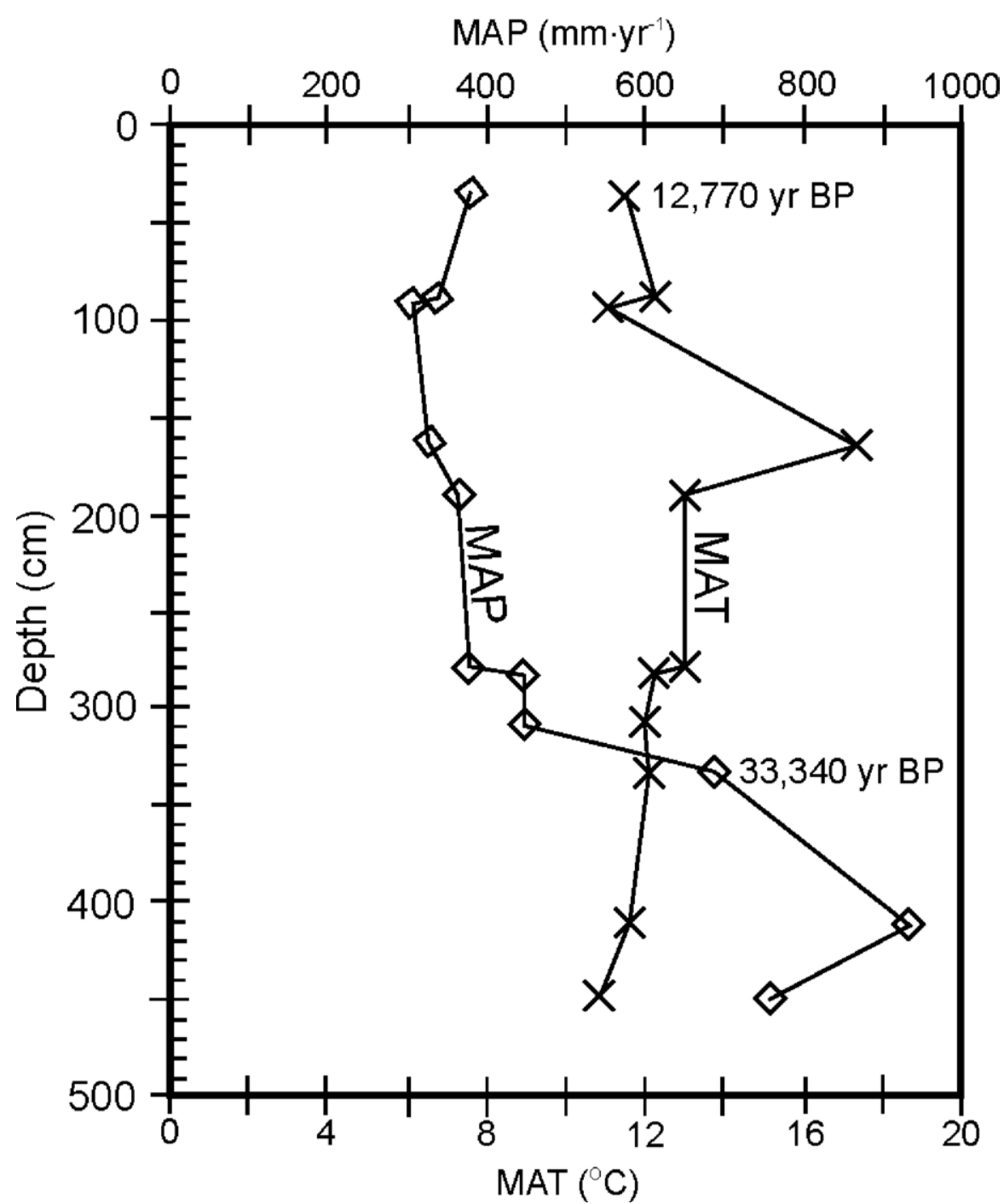

Figure 7. Mean Annual Precipitation (MAP) and Mean Annual Temperature (MAT) of the study site.
$\mathrm{Ba} / \mathrm{Sr}$ : leaching intensity

Heavily-leached sediments have depleted $\mathrm{Ba} / \mathrm{Sr}$ ratios, and an increase in value reflects less leaching (Sheldon, 2006). All of our results reveal low $\mathrm{Ba} /$ $\mathrm{Sr}$ ratios near the top of the profile, while the ratio increases in the lower profile, indicating that most layers of the upper zones were more intensely leached than those in the lower zone. This feature could possibly be caused by rainwater that worked through the profile during diagenesis and over time, as the site is situated in a tropical climate environment.

\section{Other trace elements}

Other trace elements, e.g., $\mathrm{Ni}, \mathrm{V}$, $\mathrm{Rb}$, and $\mathrm{Cr}$, play significant roles as indicators of the sedimentary environment. Their range may reflect the past humidity conditions in the depositional environment (Aubert and Pinta, 1977) or tropical/humid regions, and some ranges can determine the sediment provenance, as discussed below.

The highest contents of nickel are in ultramafic rocks (e.g., peridotite, dunite: 1,200-2,000 ppm) and their metamorphic products (e.g., serpentinite: 500 ppm), as well as in mafic rocks (e.g., basalt, gabbro: 150 ppm). However, nickel is low in acid rocks (e.g., granite: 5-10 ppm) and in sediments, e.g., sandstones: 90 ppm, loams and clays: $90-100$ ppm, loessic loams: $20-30 \mathrm{ppm}$, calcareous rocks: $10-20 \mathrm{ppm}$, and certain quartzlike rocks: 2 ppm (Aubert and Pinta, 1977).

Hydromorphic (excess moisture) alluvial sandy clay sediments in Chad and Madagascar contain 20-30 ppm and 45-60 ppm of Ni, respectively. A study in Madagascar found that sandy loam and sandy clay sediments of its flood terrace and alluvial bank contain 178-120 ppm of Ni (Aubert and Pinta, 1977). The Ni contents in this study range from 55 to $99 \mathrm{ppm}$, with an average of $67 \mathrm{ppm}$ and closely match the alluvial hydromorphic sandy clay sediments located in the tropical/humid regions of Madagascar. The values may be governed by parent rocks.

The parent rock plays an important role in vanadium-bearing sediments (e.g., granite: 3-60 ppm, gneiss: 100-150 ppm, amphibolite: 100-300 ppm, phyllite: 50-200 ppm, mafic material: 200-300 ppm) (Aubert and Pinta, 1977). The $V$ contents of the samples in this study range from 70 to $160 \mathrm{ppm}$ with an average of $119 \mathrm{ppm}$. Vanadium contents in sediments in tropical/humid regions range from traces to $300 \mathrm{ppm}$, and leached hydromorphic soil attains $100 \mathrm{ppm}$. Therefore, the results of the $\mathrm{V}$ content from this study may indicate an ancient tropical/humid climate environment.

Rubidium, a rare alkali metal element, is found in rocks at low values (i.e., lithosphere: 3-7 ppm, ultramafic rocks: 2 ppm, mafic volcanic rocks: 45 ppm, acid volcanic rocks: 200 ppm, metamorphic rocks and clays: 200 ppm, sandstone: 60 ppm, and carbonate rocks: 3 ppm) (Turekian and Wedepohl, 1961; Aubert and Pinta, 1977). Rubidium is also found in the soil of humid and tropical regions, ranging from $<3$ to $100 \mathrm{ppm}$. Our samples contain high $\mathrm{Rb}$ values ranging from 81 to $210 \mathrm{ppm}$ with an average of $116 \mathrm{ppm}$ and covering the range of humid/tropical hydromorphic sediments in Madagascar (90-180 ppm; Nalovič, 1969). The values from this study may be affected by the acidic parent rocks.

Parent rocks play a major role in determining $\mathrm{Cr}$ content in sediment, and $\mathrm{Cr}$ is a relatively stable element. The average values of different rocks include acid eruptive rocks (e.g., granite, charnockite: 20-40 ppm), ultramafic rocks (e.g., 


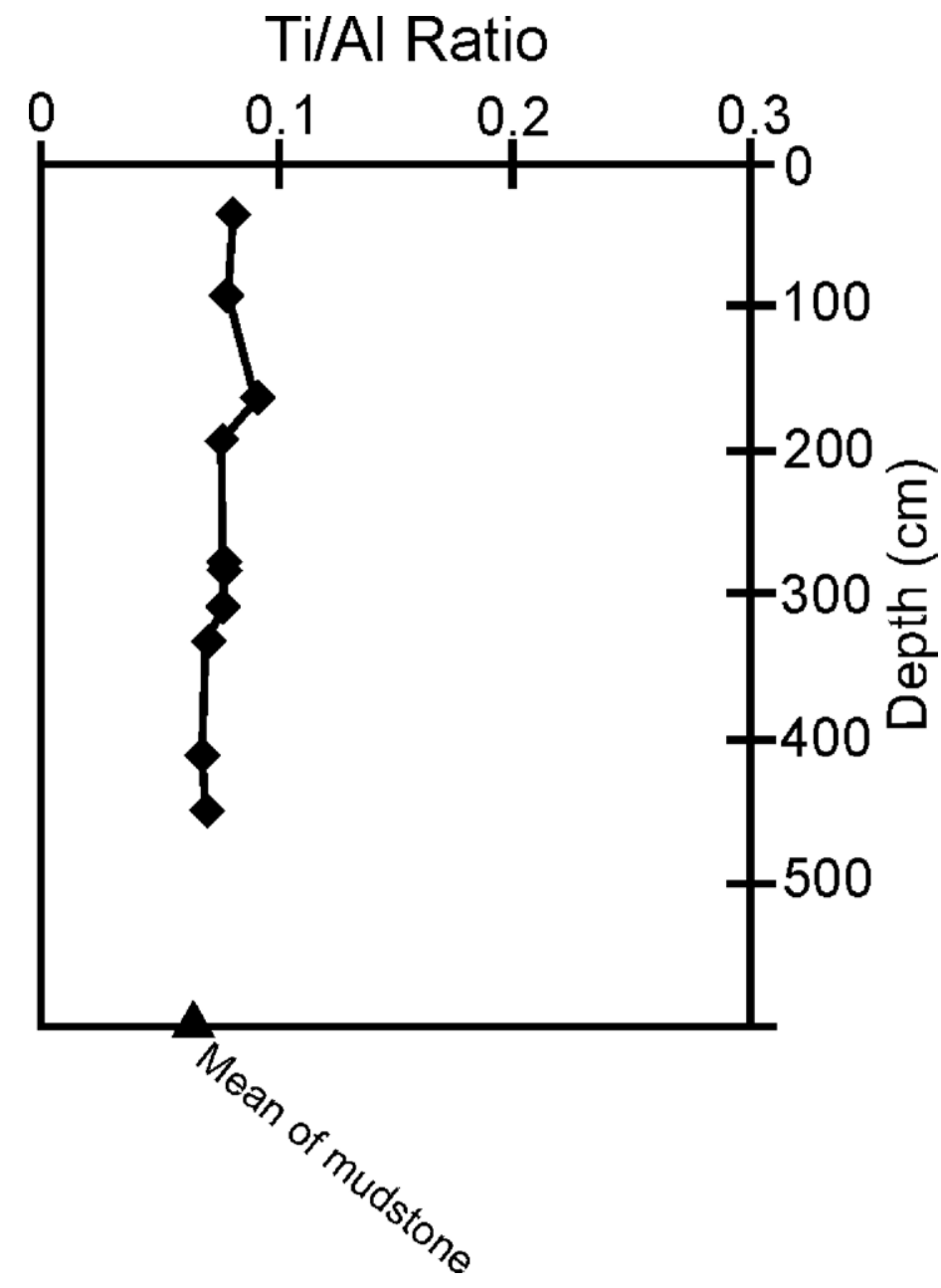

Figure 8 Plot of Ti/Al ratio against profile depth showing sediment provenance (mean values of rocks/soil from Maynard, 1992; Sheldon, 2006). The samples strongly agreed well with a mean of mudstone, suggesting derivation from a high weathering intensity environment.

dunite, peridotite: $2,000-3,000 \mathrm{ppm}$ ), and mafic rocks (e.g., basalt, dolerite: 100-300 ppm). Clays contain relatively higher $\mathrm{Cr}(100-110 \mathrm{ppm})$ than sandstones and limestones (Vinogradov, 1959; Turekian and Wedepohl, 1961). The results of this study show that $\mathrm{Cr}$ contents range from 87 to $192 \mathrm{ppm}$ with an average of $130 \mathrm{ppm}$ and are comparable to the hydromorphic clayey sediments in Chad (80-250 ppm), located in a humid/tropical zone (Aubert and Pinta, 1977).

\section{Tham Lod site in its archaeological regional context}

Prehistoric human occupation at the site, as reported by Marwick and Gagan (2011) and Chitkament et al. (2016), produced lithic and faunal remains throughout the profile and ceramics and metal items in the upper layer (Holocene Epoch). The site and the surrounding areas typically contain Hoabinhian assemblages, and the studied site has been classified in the Early Hoabinhian Phase (Kiernan et al., 1988). The Chalcolithic human occupations, which emphasized food production, were abundant according to the Neolithic record in northern Atlantic Spain (Straus, 2018).

Bone fragments and charcoal debris (Fig. 4) are visible in the profile in layers $2-4,>12,770-30,970 \mathrm{yr}$ BP (Marwick and Gagan, 2011), and many thin sections contain bone fragments. Micromorphology provides evidence of profuse bone fragments in layers 3,4 , and 5 (23,050-31,760 yr BP, Marwick and Gagan, 2011), which strongly confirm human occupation from as early as $32,000 \mathrm{yr}$ BP. The archaeological record reveals the involvement of prehistoric humans and palaeoclimate/environment interrelationships. The $\mathrm{P}_{2} \mathrm{O}_{5}$ values in the sediments at depths between 35 and $283 \mathrm{~cm}$ (from samples N-TLRS-1 to W-TLRS-7, 12,770-31,760 yr BP) are higher than those in the lower zone $(238$ to $450 \mathrm{~cm}$, $>31,760 \mathrm{yr}$ BP, Marwick and Gagan, 2011). This result reflects the heavy input of animal and human bones in the site (Kehl et al., 2014) during this period (12,770 to $31,760 \mathrm{yr}$ BP, Marwick and Gagan, 2011). Comparable to this site and dated to this period is the cave in Istria, Croatia, where the uppermost Late Upper Palaeolithic occupation layers 12,460 yr BP contain an abundance of lithic cores, flakes, and tools from local flints (Miracle, 2001).

Humans occupied the upper zone because the environment was less humid and the shelter floor was above the Lang River water as the area became a terrace. The dominant sources of sediments are autochthonous and anthropogenic and develop colluvial deposition under the shelter. Most of the archaeological sites located on the low terraces and bedrock promontories along the main river channel and its tributary streams suggest traditional hunter-gatherer lifestyles supplemented by a pastoral economy (Chlachula and Krupyanko, 2016). Many lithic raw materials were brought to the shelter because the site was a manufactury of stone tools, and fragments $(<100 \mathrm{~mm})$ and core stones, mainly grey sandstone, are found. This feature could be interpreted as the prospering of Hoabinhian tools in the period between approximately 26,000 and 20,000 yr BP, while the climate was stable during the Last Glacial Maximum (LGM) (Penny, 2001; Marwick and Gagan, 2011; Chitkament et al., 2016).

Climate changes influence resources and ecology, as well as influence Hoabinhian technology (Marwick, 2013). The lower zones, especially layers 7 and 8 (>34,130 yr BP), contain abundant fluvial pebbles and cobbles; the site was submerged in the palaeoriver Lang, and no human activity evidence is found in this period. New occupations arose during the warm mid-glacial (MIS 3; 55,000-24,000 yr BP) climatic variations marked by the shift in forest vegetation. The Hoabinhian technologies suggest a culture similar to that of the late Pleistocene in north-central Asia (Chlachula, 2017). Favorable environmental conditions during the mid-last glacial interval (30,000-24,000 yr BP) encouraged an expansion of occupations that matched and synchronized with Upper Palaeolithic cultures (Slobodin, 1999; Ponkratova, 2007). 
Table 4 Relative quantity of clay minerals and chemical composition of sediment samples at Tham Lod rock shelter.

\begin{tabular}{|c|c|c|c|c|c|c|c|c|c|c|c|c|}
\hline Sample & 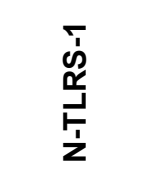 & 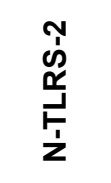 & 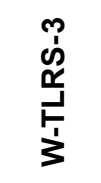 & 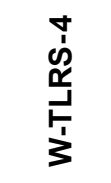 & 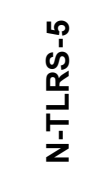 & 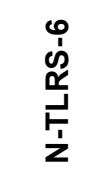 & 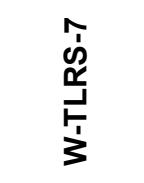 & $\begin{array}{l}\infty \\
\dot{1} \\
\tilde{\alpha} \\
\dot{1} \\
\dot{5} \\
\dot{3}\end{array}$ & 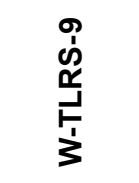 & 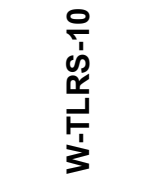 & 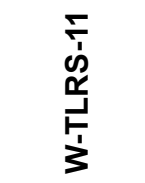 & $\begin{array}{l}\frac{0}{0} \\
\frac{\pi}{0} \\
\frac{3}{4}\end{array}$ \\
\hline Depth of sampling (cm) & 35 & 88 & 93 & 164 & 190 & 280 & 283 & 309 & 333 & 412 & 450 & \\
\hline In layer & 1 & 2 & 2 & 3 & 3 & 4 & 5 & 6 & 7 & 8 & 8 & \\
\hline $\begin{array}{l}\text { Age (Year, Marwick and } \\
\text { Gargan, 2011) }\end{array}$ & 12,770 & $\mathrm{~N} / \mathrm{A}$ & 17,510 & 23,050 & 24,640 & 30,970 & 31,760 & 33,340 & 34,130 & $N / A$ & $N / A$ & \\
\hline \multicolumn{13}{|l|}{$\begin{array}{l}\text { Relative quantity of clay } \\
\text { minerals }\end{array}$} \\
\hline Kaolinite & Small & Trace & Small & Small & Trace & Trace & Small & Small & Moderate & Moderate & Moderate & \\
\hline Illite & Small & Trace & $\mathrm{N} / \mathrm{A}$ & Small & Trace & Trace & Small & Small & Small & Small & Moderate & \\
\hline Smectite & Dominant & Large & $\mathrm{N} / \mathrm{A}$ & $\mathrm{N} / \mathrm{A}$ & Large & Large & Moderate & Moderate & Small & Small & $\mathrm{N} / \mathrm{A}$ & \\
\hline \multicolumn{13}{|l|}{ Major elements (wt\%) } \\
\hline $\mathrm{Al}_{2} \mathrm{O}_{3}$ & 13.54 & 13.46 & 11.18 & 15.13 & 14.67 & 14.96 & 15.70 & 15.52 & 17.70 & 17.71 & 16.14 & 15.06 \\
\hline $\mathrm{Fe}_{2} \mathrm{O}_{3}$ & 7.20 & 7.28 & 6.37 & 10.25 & 8.39 & 8.59 & 8.17 & 8.03 & 8.40 & 8.18 & 8.05 & 8.08 \\
\hline $\mathrm{P}_{2} \mathrm{O}_{5}$ & 2.86 & 3.21 & 4.35 & 3.76 & 2.88 & 3.36 & 2.38 & 2.17 & 0.98 & 0.44 & 0.51 & 2.45 \\
\hline $\mathrm{K}_{2} \mathrm{O}$ & 3.62 & 2.14 & 2.01 & 2.14 & 1.86 & 1.43 & 2.03 & 2.08 & 2.53 & 2.86 & 2.74 & 2.31 \\
\hline $\mathrm{MgO}$ & 1.52 & 1.31 & 1.06 & 1.54 & 1.43 & 1.43 & 1.30 & 1.26 & 1.10 & 1.10 & 0.92 & 1.27 \\
\hline $\mathrm{MnO}$ & 0.91 & 0.98 & 0.85 & 1.41 & 1.07 & 1.06 & 0.95 & 0.85 & 0.94 & 0.60 & 0.58 & 0.93 \\
\hline $\mathrm{Na}_{2} \mathrm{O}$ & 0.16 & 0.15 & 0.13 & 0.05 & 0.19 & 0.17 & 0.13 & 0.14 & 0.09 & 0.08 & 0.07 & 0.12 \\
\hline $\mathrm{SiO}_{2}$ & 49.74 & 44.80 & 43.55 & 31.39 & 45.26 & 46.08 & 53.02 & 53.76 & 60.20 & 64.59 & 64.82 & 50.65 \\
\hline $\mathrm{TiO}_{2}$ & 0.85 & 0.83 & 0.69 & 1.08 & 0.86 & 0.90 & 0.91 & 0.92 & 0.97 & 0.95 & 0.89 & 0.90 \\
\hline $\mathrm{CaO}$ & 19.56 & 25.84 & 29.79 & 33.19 & 23.37 & 22.01 & 15.39 & 15.25 & 7.06 & 3.45 & 5.23 & 18.20 \\
\hline $\begin{array}{l}\text { Total (Recast to } 100 \% \text {, } \\
\text { no LOI) }\end{array}$ & 99.96 & 100.00 & 99.99 & 99.94 & 100.00 & 100.00 & 99.97 & 99.96 & 99.96 & 99.95 & 99.96 & 99.97 \\
\hline LOI & 16.42 & 19.67 & 19.97 & $\mathrm{~N} / \mathrm{A}$ & 18.57 & 17.6 & 14.78 & 14.48 & 10.88 & 8.35 & 9.13 & 14.99 \\
\hline \multicolumn{13}{|l|}{ Trace elements (ppm.) } \\
\hline $\mathrm{Ni}$ & 63 & 57 & 62 & 99 & 55 & 57 & 65 & 61 & 72 & 68 & 83 & 67 \\
\hline V & 70 & 88 & 90 & 160 & 94 & 103 & 121 & 122 & 148 & 158 & 160 & 119 \\
\hline $\mathrm{Rb}$ & 103 & 81 & 84 & 210 & 83 & 82 & 104 & 108 & 131 & 144 & 143 & 116 \\
\hline Y & 9 & 7 & 51 & 56 & 9 & 8 & 9 & 8 & 12 & 13 & 78 & 24 \\
\hline $\mathrm{Nb}$ & 1 & 0 & 8 & 41 & 2 & 1 & 3 & 5 & 7 & 9 & 17 & 9 \\
\hline Th & $\mathrm{N} / \mathrm{A}$ & $\mathrm{N} / \mathrm{A}$ & 8 & $\mathrm{~N} / \mathrm{A}$ & $\mathrm{N} / \mathrm{A}$ & $\mathrm{N} / \mathrm{A}$ & $\mathrm{N} / \mathrm{A}$ & $\mathrm{N} / \mathrm{A}$ & $\mathrm{N} / \mathrm{A}$ & $\mathrm{N} / \mathrm{A}$ & 18 & 13 \\
\hline $\mathrm{Cr}$ & 114 & 97 & 87 & 192 & 101 & 110 & 126 & 128 & 165 & 161 & 148 & 130 \\
\hline $\mathrm{Sr}$ & 117 & 147 & 175 & 335 & 110 & 94 & 77 & 72 & 53 & 36 & 67 & 117 \\
\hline $\mathrm{Ba}$ & 219 & 182 & 818 & $\mathrm{~N} / \mathrm{A}$ & 161 & 171 & 191 & 185 & 232 & 174 & 796 & 313 \\
\hline Sc & 57 & 64 & 66 & $\mathrm{~N} / \mathrm{A}$ & 58 & 58 & 42 & 46 & 21 & 9 & 13 & 43 \\
\hline $\mathrm{Zr}$ & 168 & 149 & 137 & 379 & 151 & 162 & 188 & 180 & 217 & 231 & 216 & 198 \\
\hline CIA Value & 36.68 & 32.36 & 25.93 & 29.92 & 36.6 & 38.79 & 47.21 & 47.02 & 64.55 & 73.36 & 66.6 & 45.37 \\
\hline Al/Si Ratio & 0.16 & 0.18 & 0.15 & 0.28 & 0.19 & 0.19 & 0.17 & 0.17 & 0.17 & 0.16 & 0.15 & 0.18 \\
\hline Ti/AI Ratio & 0.08 & 0.079 & 0.078 & 0.091 & 0.075 & 0.077 & 0.075 & 0.076 & 0.07 & 0.068 & 0.07 & 0.08 \\
\hline $\mathrm{Ba} / \mathrm{Sr}$ Ratio & 1.87 & 1.24 & 4.68 & $\mathrm{~N} / \mathrm{A}$ & 1.45 & 1.81 & 2.49 & 2.57 & 4.38 & 4.82 & 11.96 & 3.73 \\
\hline MAP (mm/yr) & 379 & 342 & 309 & 328 & 366 & 377 & 447 & 446 & 687 & 935 & 757 & 488 \\
\hline MAT $\left({ }^{\circ} \mathrm{C}\right)$ & 11.5 & 12.3 & 11.1 & 17.3 & 13.0 & 13.0 & 12.2 & 12.0 & 12.1 & 11.6 & 10.9 & 12.4 \\
\hline
\end{tabular}

$\mathrm{N} / \mathrm{A}=$ Not available; $\mathrm{CIA}=$ Chemical Index of Alteration; MAP $=$ Mean Annual Precipitation; MAT $=$ Mean Annual Temperature. 


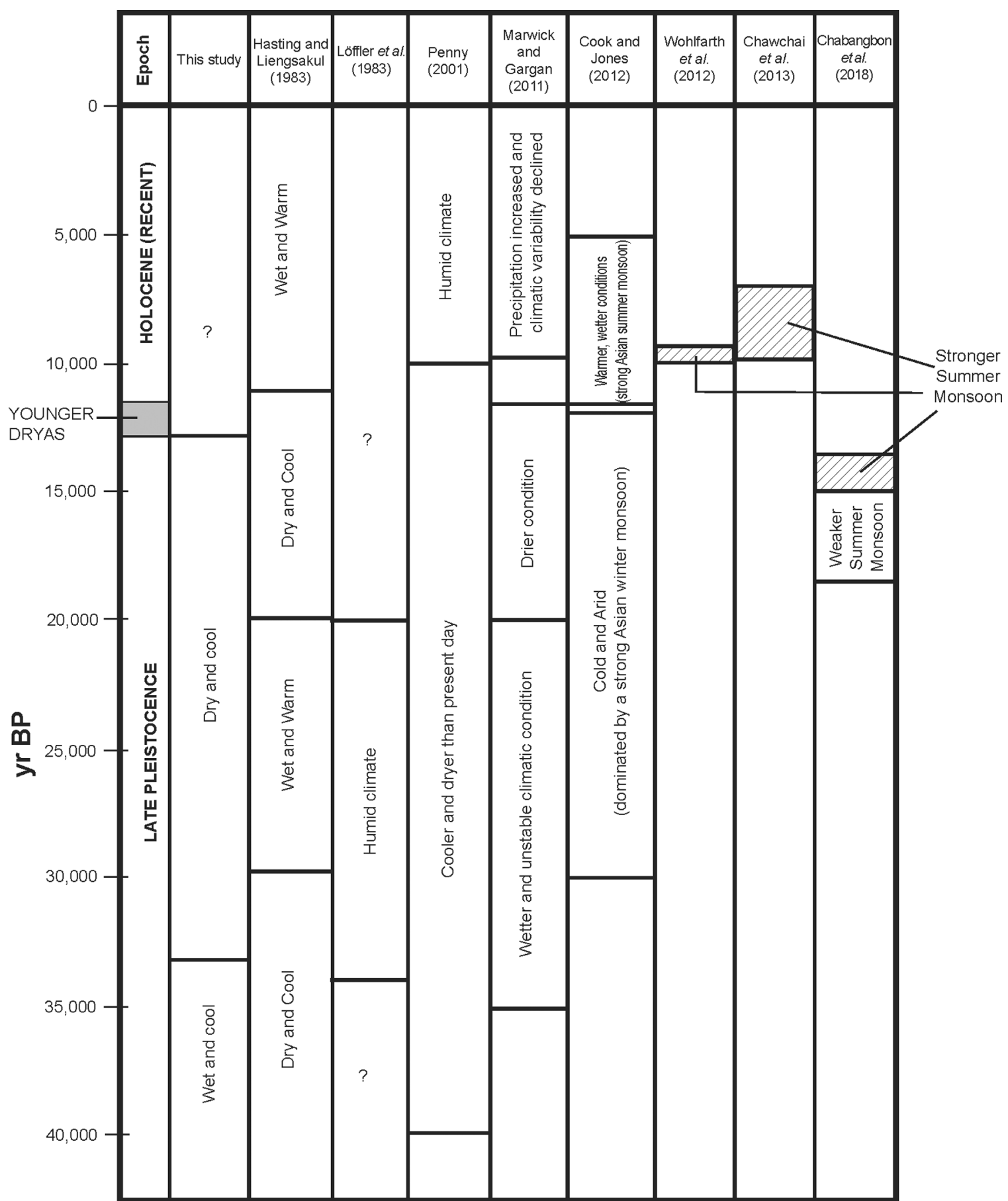

Figure 9 Palaeoclimate from the Late Pleistocene to early Holocene at the study site, compared to other locations in Thailand and Southeast Asia.

sediments have been performed by several scholars (e.g., Goldberg, 2000; Courty and Vallverdu, 2001; Woodward and Goldberg, 2001; Woodward et al., 2001; Karkanas, 2002). The data from sediments at Lake Kumphawapi, northeast Thailand, imply the late Pleistocene palaeoclimate of Thailand and Southeast Asia (Hasting and Liengsakul, 1983; Pramojanee and Hastings, 1983; Penny, 2001). Marwick and Gagan (2011) invoked cool and dry climate conditions in the studied site. Our study reveals palaeoclimates between $\sim 34,130 \mathrm{yr}$ BP and $\sim 12,770 \mathrm{yr}$ BP. Palynological study of the glacial-age vegetation in peat profiles from northeast Thailand demonstrates the climatic conditions between 40,000 and 10,000 yr BP, which were cooler and drier than at the present (Penny, 2001). The ${ }^{14} \mathrm{C}$ dating of wood and pollen in sediments showed climate changes in Thailand as follows: 60,000-30,000 yr BP: dry and cool; 30,000-20,000 yr BP: wet and warm; and 20,000-11,000 yr BP: dry and cool (Hasting and Liengsakul, 1983). This sequence can be compared and contrasted with the conclusions in some points, especially in the upper zone of the profile $(33,340-12,770 \mathrm{yr}$ 
BP, Marwick and Gagan, 2011), showing a mean annual precipitation range (309-447 mm/yr) less than that of the lower zone ( $\geq 34,130 \mathrm{yr} \mathrm{BP}$ ) with an average of $687-935 \mathrm{~mm} / \mathrm{yr}$. In the episode before 33,340 $\mathrm{yr} \mathrm{BP}$, the area would have been subjected to a wetter climate with an average total precipitation of $935 \mathrm{~mm} \mathrm{yr}^{-1}$ and a mean annual temperature ranging from 10.88 to $12.13^{\circ} \mathrm{C}$. Oxygen isotope ratios in stalagmites from caves in Socotre Island, Indian Ocean (Burns et al., 2003), suggested that the changes in monsoon precipitation and climate from 42,000 to $55,000 \mathrm{yr}$ BP are linked to varying intensities of tropical convective activity in tropical hydrological cycles in the Indian Ocean and over Southeast Asia. The stalagmites from Yelang Cave, central Guizhou, China (Zhao et al., 2017) showed that from 33,400 to 36,000 $\mathrm{yr} \mathrm{BP}$, the area was dry very cold and dry climates with poor vegetation and warming and very wet climates with the best vegetation coverage during 9,000-11,500 yr BP corresponding to a maximum insolation.

Stalagmites from Songjia Cave, central China, (Zhou et al., 2008) showed significant variation in past climate and environment. The coldest climatic phase since the Last Glacial Maximum was clearly recorded between 17,600 and $14,500 \mathrm{yr} B P$, suggesting that there were synchronous and significant climatic changes across monsoonal China and strong remote connections between the North Atlantic and East Asia regions during the period 20,000-10,000 yr BP. The late Pleistocene palaeoclimate from Sun and $\mathrm{Li}(1999)$ in an area of the South China Sea revealed that from the glacial period variations appeared between cool/humid and dry/temperate as climatic cycles on the millennial scale. The climatic condition of 15,000-11,300 yr BP was explained by significant vegetation changes that increased the amount of tropical/subtropical broad-leaved taxa with a spike of mangrove pollen approximately 14,000 yr BP. Moreover, a cold phase lasted from 12,800 to 11,500 yr BP during the Younger Dryas period. This interpretation also explains the climatic conditions of the Holocene Epoch (the last 11,500 yr BP), which are similar to those of the present time (Sun and $\mathrm{Li}, 1999)$. The episode fell within the period of the end of the last ice age ( 15,000-8000 yr BP), and sea level rise impelled the human population to change their lifestyle from hunting to agriculture (Birch and Linden, 2018). The sea level change during the postglacial period caused substantial changes in the natural environment and human ecology.

However, Figure 9 summarizes and compares the palaeoclimate of Thailand during the period between the late Pleistocene and the early Holocene. Our data indicate that 33,340 to 12,700 yr BP was cooler and drier than the present time, which coincided with the Last Glacial Maximum Period. This result agrees well with certain literature for the same periods e.g., Penny (2001). However, the data from 20,000 to 35,000 yr BP do not seem to agree with Hasting and Liengsakul (1983), Löffler, et al. (1983), and Marwick and Gagan, (2011), which might be the variation of the climate in local areas. The recent average annual rainfall and temperature (30 years, from 1981-2010) at the Pang Mapha station near the study area were $1,200 \mathrm{~mm} \mathrm{yr}^{-1}$ and $25.5^{\circ} \mathrm{C}$, respectively (Climatological Center, Thai Meteorological Department, 2018), compared to the cooler and drier palaeoclimate from this study during the period of 34,130-12,770 yr BP.

After 34,130 yr BP, the MAP ranged from 309 to $447 \mathrm{~mm} \mathrm{yr}^{-1}$ and the MAT was from 11.1 to $13^{\circ} \mathrm{C}$, which indicates that the LGM affected South East Asia climate and the climate of Pang Mapha area. An abrupt change from a more humid environment to drier conditions, is evidenced by the record in the studied sediments at the depth of $333 \mathrm{~cm}$ or about $34,130 \mathrm{yr}$ BP. Before that, the MAP rising up to $935 \mathrm{~mm} \mathrm{yr}^{-1}$, which is close to the present value $\left(1,200 \mathrm{~mm} \mathrm{yr}^{-1}\right)$, but the MAT is lower than the present value $\left(25.5^{\circ} \mathrm{C}\right)$, suggesting that the present climate in the area is affected by the dense forest. In other words, the vegetation of SEA in the late Pleistocene would have been more abundant than the present time. The forest kept more humidity for the area even the temperature is relatively lower than the present.

\section{Conclusion}

Micromorphology, mineralogy, and geochemistry provide distinct and non-distinct data about humidity or wet and dry cycles in the area of Pang Mapha in Mae Hong Son, Thailand and SEA. The data reveal that the late Pleistocene climate was humid and tropical. During the time $\geq 33,340 \mathrm{yr}$ BP, the climate was wet and cool, and later from 33,340 to $12,770 \mathrm{yr}$ BP, it was drier and cooler than the present day with certain variability to the short warmer/wetter period. Prehistoric humans occupied the site between 33,340 and 12,770 yr BP (during the Last Glacial Maximum Period) which is in agreement with high phosphate contents. The animal and human bones at the site suggest animal hunting by ancient humans.

\section{Acknowledgments}

Our special thanks to Nathsuda Pumijumnong, Monthira Yuttitham, and Worachart Wisawapipat for their suggestions to develop this article. This work was supported by Thailand Research Funds, TRF (grant number RDG55H0006). We are in debt to the people, working on the Highland Archeological Project in Pang Mapha, conducted by Rasami Shoocongdej, who facilitated our fieldwork. We thank the students of the Department of General Science, SWU for their help in collecting and analyzing samples as well as the Land Development Department and Royal Irrigation Department for sample analyses. We would also like to thank Simon Mclver, Tipa Thep-Ackrapong, Alfredo Villarroel, Kanu Priya Mohan, and Pitthayut Saminpanya who proofread the manuscript. Thanks also go to Richard I. Macphail for his consultation on thin-section identification. 


\section{References}

Alam, A.K.M.M., Xie, S., Saha, D.K., and Chowdhury, S.Q., 2008, Clay mineralogy of archaeological soil: an approach to paleoclimatic and environmental reconstruction of the archaeological sites of the Paharpur area, Badalgacchiupazila, Naogaon district, Bangladesh: Environmental Geology, v. 53, p. 1639-1650. https://doi.org/10.1007/s00254-007-0771-1

Aubert, H., and Pinta, M., 1977, Trace elements in soils: New York, Elsevier Scientific, 394 p.

Bedaiwy, M.N.A., 2012, A simplified approach for determining the hydrometer's dynamic settling depth in particle-size analysis: Catena, v. 97 , p. 95-103. https://doi.org/10.1016/j.catena.2012.05.010

Bengtsson, L., and Enell, M., 1986, Chemical analysis, in Berglund, B.E., ed., Handbook of Holocene Palaeoecology and Palaeohydrology: Chichester, John Wiley \& Sons Ltd., p. 423-451.

Bhattacharyya, T., Pal, D.K., and Deshpande, S.B., 1993, Genesis and transformation of minerals in the formation of red (Alfisols) and black (Inceptisols and Vertisols) soils on Deccan basalt in the Western Ghats, India: Journal of Soil Science, v. 44, p. 159-171. https://doi. org/10.1111/j.1365-2389.1993.tb00442.x

Birch, S.E.P., and Linden, M.V., 2018, A long hard road... Reviewing the evidence for environmental change and population history in the eastern Adriatic and western Balkans during the Late Pleistocene and Early Holocene: Quaternary International, v. 465, p. 177-191. https://doi. org/10.1016/j.quaint.2016.12.035

Blokhuis, W.A., Kooistra, M.J., and Wilding, L.P., 1990, Micromorphology of cracking clayey soils (Vertisols), in Douglas, L.A., ed., Micromorphology: A Basic and Applied Science. Developments in Soil Science, Volume 19: Amsterdam, Elsevier, p. 123-148. https://doi.org/10.1016/ S0166-2481(08)70323-4

Blokhuis, W.A., Pape, T., and Slager, S., 1969, Morphology and distribution of pedogenic carbonate in some Vertisols of the Sudan: Geoderma, v. 2, p. 173-200. https://doi.org/10.1016/0016-7061(69)90037-8

Burns, S.J., Fleitmann, D., Matter, A., Kramers, J., and Al-Subbary, A.A., 2003, Indian Ocean Climate and an Absolute Chronology Over Dansgaard/Oeschger Events 9 to 13: Science, v. 301, p. 1365-1367. https://doi.org/10.1126/science.1086227

Chabangbon, A., Yamoah, K.K.A., Phantuwongraj, S., and Choowong, M., 2018, Climate in Sundaland and Asian monsoon variability during the last deglaciation: Quaternary International, v. 479, p. 141-147. https://doi.org/10.1016/j.quaint.2017.04.017

Chamley, H., 1989, Clay Sedimentology: Heidelberg, Springer-Verlag., 644 p. https://doi.org/10.1007/978-3-642-85916-8

Chawchai, S., Chabangborn, A., Kylander, M., Löwemark, L., Mörth, C.-M., Blaauw, M., Klubseang, W., Reimer, P.J., Fritz, S.C., and Wohlfarth, B., 2013, Lake Kumphawapi - an archive of Holocene palaeoenvironmental and palaeoclimatic changes in northeast Thailand: Quaternary Science Reviews, v. 68, p. 59-75. https://doi.org/10.1016/j.quascirev.2013.01.030

Chen, H.-F., Yen, P.-Y., Song, S.-R., Hsu, S.C., Yang, T.N., Wang, Y., Chi, Z., Lee, T.-Q., Chen, M.-T., Cheng, C.-L., Zou, J., and Chang, Y.-P., 2013, The Ti/Al molar ratio as a new proxy for tracing sediment transportation processes and its application in aeolian events and sea level change in East Asia: Journal of Asian Earth Sciences, v. 73, p. 31-38. https://doi.org/10.1016/j.jseaes.2013.04.017

Chitkament, T., Gaillard, C., and Shoocongdej, R., 2016, Tham Lod rock shelter (Pang Mapha district, north-western Thailand): Evolution of the lithic assemblages during the Late Pleistocene: Quaternary International, v. 416, p. 151-161. https://doi.org/10.1016/j.quaint.2015.10.058

Chlachula, J., 2017, Chronology and environments of the Pleistocene peopling of North Asia: Archaeological Research in Asia, v. 12, p. 33-53. https://doi.org/10.1016/j.ara.2017.07.006

Chlachula, J., and Krupyanko, A.A., 2016, Sequence stratigraphy and environmental background of the late Pleistocene and Holocene occupation in the Southeast Primor'ye (the Russian Far East): Quaternary Science Reviews, v. 142, p. 120-142. https://doi.org/10.1016/j.quascirev.2016.03.018

Clemens, S.C., Prell, W.L., and Sun, Y., 2010, Orbital-scale timing and mechanisms driving Late Pleistocene Indo $\square$ Asian summer monsoons: Reinterpreting cave speleothem $\delta^{18}$ O: PALEOCEANOGRAPHY, v. 25, p. 1-19. https://doi.org/10.1029/2010PA001926

Climatological Center, Thai Meteorological Department, 2018, Mae Hong Son Climate, [WWW Document], n.d. URL http://climate.tmd.go.th/ data/province/เหนือ/ภูมิ อากาศแม่ฮ่องสอน.pdf (accessed on 24 June 2018).

Cook, C.G., and Jones, R.T., 2012, Palaeoclimate dynamics in continental Southeast Asia over the last $\sim 30,000$ Cal yrs BP: Palaeogeography, Palaeoclimatology, Palaeoecology, v. 339-341, p. 1-11. https://doi.org/10.1016/j.palaeo.2012.03.025

Courty, M.A., and Vallverdu, J., 2001, The microstratigraphic record of abrupt climate changes in cave sediments of the Western Mediterranean: Geoarchaeology, v. 16, p. 467-499. https://doi.org/10.1002/gea.1002

Dean, W.E.Jr., 1974, Determination of carbonate and organic matter in calcareous sediments and sedimentary rocks by loss on ignition: Comparison with other methods: Journal of Sedimentary Petrology, v. 44, p. 242-248. https://doi.org/10.1306/74D729D2-2B21-11D78648000102C1865D

Department of Mineral Resources, Thailand, 2017, Geological Map 1:250,000 (http://wms2.dmr.go.th/gisdmr_kml.html) (accessed on 29 November 2018).

Dixon, J.B., and Weed, S.B., 1989, Minerals in soil environments, $2^{\text {nd }}$ ed.: Madison, Soil Science Society of America, 89 p. https://doi. org/10.2136/sssabookser1.2ed.c5

Du, S., Li, X., Zhou, L., Pang, H., Bar-Yosef, O., and Wu, X., 2016, Longquan Cave: an early Upper Palaeolithic site in Henan Province, China: Antiquity, v. 90, p. 876-893. https://doi.org/10.15184/aqy.2016.108

Goldberg, P., 2000, Micromorphology and site formation at Die Kelders Cave I, South Africa: Journal of Human Evolution, v. 38, p. 43-90. https:// doi.org/10.1006/jhev.1999.0350

Hamer, J.M., Sheldon, N.D., and Nichols, G.J., 2007, Global aridity during the Early Miocene? A terrestrial palaeoclimate record from the Ebro Basin, Spain: The Journal of Geology, v. 115, p. 601-608. https://doi.org/10.1086/519780

Hasting, P.J., and Liengsakul, M., 1983, Chronology of the late Quaternary climatic changes in Thailand, in Proceedings, The First Symposium on Geomorphology and Quaternary Geology of Thailand: Bangkok, Department of Geology, Chulalongkorn University, p. 24-34.

Heiri, O., Lotter, A.F., and Lemcke, G., 2001, Loss on ignition as a method for estimating organic and carbonate content in sediments: reproducibility and comparability of results: Journal of Paleolimnology, v. 25, p. 101-110. https://doi.org/10.1023/A:1008119611481

Hong, H., Gu, Y., Yin, K., Wang, C., and Li, Z., 2013, Clay record of climate change since the mid- Pleistocene in Jiujiang, south China: Boreas, v. 42, p. 173-183. https://doi.org/10.1111/j.1502-3885.2012.00276.x

lacoviello, F., and Martini, I., 2013, Clay minerals in cave sediments and terra rossa soils in the Montagnola Senese karst massif (Italy): Geological Quarterly, v. 57, p. 527-536. https://doi.org/10.7306/gq.1111

Jackson, M.L., 2005, Soil Chemical Analysis: Advanced course, revised $2^{\text {nd }}$ ed.: Medison, Parallel Press, 930 p. 
Kabakchiev, I., and Galeva, V., 1973, Comparative micromorphological investigation of cernozemsmonitzas and chernozems [in Bulgarian]: Pochvoznanie i Agrokhimiya, v. 8, p. 11-24.

Karkanas, P., 2002, Micromorphological studies of Greek prehistoric sites, New insights in the interpretation of the archaeological record: Geoarchaeology, v. 17, p. 237-259. https://doi.org/10.1002/gea.10012

Kehl, M., Eckmeier, E., Franz, S.O., Lehmkuhl, F., Soler, J., Soler, N., Reicherter, K., and Weniger, G.C., 2014, Sediment sequence and site formation processes at the Arbreda Cave, NE Iberian Peninsula, and implications on human occupation and climate change during the Last Glacial: Climate of the Past, v. 10, p. 1673-1692. https://doi.org/10.5194/cp-10-1673-2014

Khaokhiew, C., 2003, Geoarchaeology: site formation process of Tham Lod rock shelter, Pang Mapha District, Mae Hong Son Province [M.Sc. thesis]. Bangkok, Silpakorn University. 164 p. (in Thai).

Kiernan, K., Spies, J., and Dunkley, J., 1988, Prehistoric occupation and burial sites in the mountains of the Nam Khong area, Mae Hong Son province, northwestern Thailand: Australian Archaeology, v. 27, p. 24-44. https://www.jstor.org/stable/40286659

Krauskopf, K., and Bird, D.K., 1995, Introduction to Geochemistry, $3^{\text {rd }}$ ed.: New York, McGraw-Hill, Inc., 640 p.

Löfler, E., Thaompson, W.P., and Liengsakul, M., 1983, Geomorphological development of the Tung Kula Ronghai, in Proceedings, The First Symposium on Geomorphology and Quaternary Geology of Thailand: Bangkok, Department of Geology, Chulalongkorn University, p. 123-130.

Marwick, B., 2013, Multiple Optima in Hoabinhian flaked stone artifact palaeoeconomics and palaeoecology at two archaeological sites in Northwest Thailand: Journal of Anthropological Archaeology, v. 32, p. 553-564. https://doi.org/10.1016/j.jaa.2013.08.004

Marwick, B., and Gagan, M.K., 2011, Late Pleistocene monsoon variability in northwest Thailand: an oxygen isotope sequence from the bivalve Margaritanopsis laosensis excavated in Mae Hong Son province: Quaternary Science Reviews, v. 30, p. 3088-3098. https://doi.org/10.1016/j. quascirev.2011.07.007

Maynard, J.B., 1992, Chemistry of modern soils as a guide to interpreting Precambrian palaeosols: The Journal of Geology, v. 100 , p. $279-289$. https://doi.org/10.1086/629632

Mellars, P., 2005, The impossible coincidence. A single-species model for the origins of modern human behavior in Europe: Evolutionary Anthropology, v. 14, p. 12-27. https://doi.org/10.1002/evan.20037

Miracle, P., 2001, Feast or Famine? Epi-Paleolithic subsistence in the northern Adriatic basin: Documenta Praehistorica, v. 26, p. $177-197$. https://doi.org/10.4312/dp.28.10

Muangsong, C., Cai, B., Pumijumnong, N., Hu, C., and Cheng, H., 2014, An annually laminated stalagmite record of the changes in Thailand monsoon rainfall over the past 387 years and its relationship to IOD and ENSO: Quaternary International, v. 349, p. 90-97. https://doi. org/10.1016/j.quaint.2014.08.037

Munsell Color (Firm), 2012, Munsell soil color charts: with genuine Munsell color chips. Grand Rapids, MI: Munsell Color.

Nalovič, L., 1969, Etude spectrographique des éléments traces et leur distribution dans quelques types de sols de Madagascar: Cahiers ORSTOM.Série Pédologie, v. VII, p. 133-181.

Nesbitt, H.W., and Young, G.M., 1982, Early Proterozoic climates and plate motions inferred from major element chemistry of lutites: Nature, v. 299, p. 715-717. http://dx.doi.org/10.1038/299715a0

Nesbitt, H.W., and Young, G.M., 1984, Prediction of some weathering trends of plutonic and volcanic rocks based on thermodynamic and kinetic considerations: Geochimica et Cosmochimica Acta, v. 48, p. 1523-1534. https://doi.org/10.1016/0016-7037(84)90408-3

Nesbitt, H.W., and Young, G.M., 1989, Formation and diagenesis of weathering profiles: The Journal of Geology, v. 97, p. 129-147. https://doi. org/10.1086/629290

Pal, D.K., 2014, Clay and other minerals in soils and sediments as evidence of climate change: A review: Gondwana Geological Magazine, v. 29, p. 87-94.

Pal, D.K., Deshpande, S.B., Venugopal, K.R., and Kalbande, A.R., 1989, Formation of di- and trioctahedral smectite as evidence for paleoclimatic changes in southern and central peninsular India: Geoderma, v. 45, p. 175-184. https://doi.org/10.1016/0016-7061(89)90049-9

Penny, D., 2001, A 40,000 year palynological record from north-east Thailand; implications for biogeography and palaeo-environmental reconstruction: Palaeogeography, Palaeoclimatology, Palaeoecology, v. 171, p. 97-128. https://doi.org/10.1016/S0031-0182(01)00242-5

Ponkratova, I.Yu., 2007, Ushki 5 Site (Kamchatka): recent investigations, problems and perspectives (the Palaeolithic Period): Kolymskyy Gumanitarnyy Almanach, v. 2007, p. 13-20 (in Russian).

Pramojanee, P., and Hastings, P.J., 1983, Geomorphological and palynological investigation of sea level changes in Chantaburi, SE Thailand, in Proceedings, The First Symposium on Geomorphology and Quaternary Geology of Thailand: Bangkok, Department of Geology, Chulalongkorn University, p. 35-51.

Retallack, G.J., 2000, Depth to pedogenic carbonate horizon as a palaeoprecipitation indicator? Comment and Reply COMMENT: Geology, v. 28, p. 572-572. https://doi.org/10.1130/0091-7613(2000)28<572a:DTPCHA>2.0.CO;2

Royal Thai Survey Department, 1999, Topographic Map, Series L7018, Sheet 4648 II - Doi Phak Kut, Scale 1:50,000, Bangkok, Thailand.

Santisteban, J.I., Mediavilla, R., López-Pamo, E., Dabrio, C.J., Zapata, M.B.R., García, M.J.G., Castaño, S., and Martínez-Alfaro, P.E., 2004, Loss on ignition: a qualitative or quantitative method for organic matter and carbonate mineral content in sediments?: Journal of Palaeolimnology, v. 32, p. 287-299. https://doi.org/10.1023/B:JOPL.0000042999.30131.5b

Selley, R.C., 1985, Ancient Sedimentary Environments and their sub-surface diagnosis, $3^{\text {rd }}$ ed.: London, Chapman \& Hall, 317 p. https://doi. org/10.1007/978-1-4615-5421-9

Sheldon, N.D., 2006, Abrupt chemical weathering increase across the Permian-Triassic boundary: Palaeogeography, Palaeoclimatology, Palaeoecology, v. 231, p. 315-321. https://doi.org/10.1016/j.palaeo.2005.09.001

Sheldon, N.D., and Tabor, N.J., 2009, Quantitative palaeoenvironmental and palaeoclimatic reconstruction using palaeosols: Earth-Science Reviews, v. 95, p. 1-52. https://doi.org/10.1016/j.earscirev.2009.03.004

Shepard, F.P., 1954, Nomenclature based on sand-silt-clay ratios: Journal of Sedimentary Research, v. 24, p. 151-158. https://doi.org/10.1306/ D4269774-2B26-11D7-8648000102C1865D

Sleeman, J.R., and Brewer, R., 1984, Micromorphology of some Australian cracking clay soils: in McGarity, J.W., Hoult, E.H., and So, H.B., eds., Properties and Utilization of Cracking Clay Soils, Reviews in Rural Sciences 5: University of New England, Armadale, Australia, p. 73-82.

Slobodin, S.B., 1999, Archaeology of Kolyma and Continental Priokhotye in Late Pleistocene and Early Holocene: NEISRI FEB RAS (in Russian): North-Eastern Federal University; North-East Interdisciplinary Science Research Institute, Magadan, 234 p. (in Russian).

Stoops, G., Marcelino, V., and Mees, F., eds., 2010, Interpretation of micromorphological features of soils and regoliths: Amsterdam, Elsevier, 752 p. https://doi.org/10.1016/C2009-0-18081-9 
Straus, L.G., 2018, Environmental and cultural changes across the Pleistocene-Holocene transition in Cantabrian Spain: Quaternary International, v. 465, p. 222-233. https://doi.org/10.1016/j.quaint.2016.10.005

Sun, X., and Li, X., 1999, A pollen record of the last $37 \mathrm{ka}$ in deep sea core 17940 from the northern slope of the South China Sea: Marine Geology, v. 156, p. 227-244. https://doi.org/10.1016/S0025-3227(98)00181-9

Tang, Z., Du, S, and Liu, F., 2017, Late Pleistocene changes in vegetation and the associated human activity at Beiyao Site, Central China: Review of Palaeobotany and Palynology, v. 244, p. 107-112. https://doi.org/10.1016/j.revpalbo.2017.04.002

Tawornpruek, S., Kheoruenromne, I., Suddhiprakarn, A., and Gilkes, R., 2006, Microstructure and water retention of Oxisols in Thailand: Soil Research, v. 43, p. 973-986. https://doi.org/10.1071/SR05039

Tsuji, G.Y., Watanabe, R.T., and Sakai, W.S., 1975, Influence of soil microstructure on water characteristics of selected Hawaiian soils: Soil Science Society of America Journal, v. 39, p. 28-33. https://doi.org/10.2136/sssaj1975.03615995003900010011x

Turekian, K.K., and Wedepohl, K.H., 1961, Distribution of the elements in some major units of the Earth's crust: Geological Society of America Bulletin, v. 72, p. 175-192. https://doi.org/10.1130/0016-7606(1961)72[175:DOTEIS]2.0.CO;2

Vinogradov, A.P., 1959, The Geochemistry of Rare and Dispersed Chemical Elements in Soils, $2^{\text {nd }}$ ed. (translated from Russian): New York, Consultants Bureau, $209 \mathrm{p}$.

Wohlfarth, B., Klubseang, W., Inthongkaew, S., Fritz, S.C., Blaauw, M., Reimer, P.J., Chabangborn, A., Löwemark, L., and Chawchai, S., 2012, Holocene environmental changes in northeast Thailand as reconstructed from a tropical wetland: Global and Planetary Change, v. 92-93, p. 148-161. https://doi.org/10.1016/j.gloplacha.2012.05.008

Woodward, J.C., and Goldberg, P., 2001, The sedimentary records in Mediterranean rock shelters and caves: Archives of environmental change: Geoarchaeology, v. 16, p. 327-354. https://doi.org/10.1002/gea.1007

Woodward, J.C., Hamlin, R.H.B., Macklin, M.G., Karkanas, P., and Kotjabopoulou, E., 2001, Quantitative sourcing of slackwater deposits at Boila rock shelter: A record of late glacial flooding and palaeolithic settlement in the Pindus Mountains, Northwest Greece: Geoarchaeology, v. 16, p. 501-536. https://doi.org/10.1002/gea.1003

Zhou, H., Zhao, J., Feng, Y., Gagan, M.K., Zhou, G., and Yan, J., 2008, Distinct climate change synchronous with Heinrich event one, recorded by stable oxygen and carbon isotopic compositions in stalagmites from China: Quaternary Research, v. 69, p. 306-315. https://doi. org/10.1016/j.yqres.2007.11.001

Zhao, M., Li, H.-C., Shen, C.-C., Kang, S.-C., and Chou, C.-Y., 2017, $\delta^{18} \mathrm{O}, \delta^{13} \mathrm{C}$, elemental content and depositional features of a stalagmite from Yelang Cave reflecting climate and vegetation changes since late Pleistocene in central Guizhou, China: Quaternary International, v. 452, p. 102-115. https://doi.org/10.1016/j.quaint.2016.07.022 